\title{
Energy benchmarking as a tool for energy efficient wastewater treatment: reviewing international applications
}

Ilda Clos a , Jörg Krampe ${ }^{\mathrm{a}, \mathrm{b}}$, Juan P. Alvarez-Gaitan ${ }^{\mathrm{c}}$, Christopher P. Saint ${ }^{\mathrm{a}}$, Michael D. Short ${ }^{\mathrm{d}, *}$

${ }^{a}$ Natural and Built Environments Research Centre, School of Natural and Built

Environments, University of South Australia, Mawson Lakes, South Australia 5095 Australia,

${ }^{b}$ Institute for Water Quality and Resource Management, TU Wien, Karlsplatz 13/226, 1040

Vienna, Austria

${ }^{c}$ UNSW Water Research Centre, School of Civil \& Environmental Engineering, The

University of New South Wales, Sydney, New South Wales, 2052, Australia

${ }^{d}$ Future Industries Institute, University of South Australia, Mawson Lakes, South Australia 5095, Australia

*corresponding author: Michael Short (ichael.Short@unisa.edu.au)

This is a post-peer-review, pre-copyedit version of an article published in Water Conservation Science and Engineering. The final authenticated version is available online at: http://dx.doi.org/10.1007/s41101-020-00086-6. 


\section{Abstract}

This review presents an assessment of international wastewater treatment plant (WWTP) energy benchmarking studies and provides for the first time a detailed historical evolution of seminal European benchmarking methodology for the international water sector. We commence by comparing international applications of energy performance assessment and how the different methods have been applied and have evolved. More specifically, we investigate how international studies have measured WWTP energy performance and what are the different views in relation to energy performance reference value, whether the energy consumption should be related to the number of people connected, the applied load, treated wastewater volume, and the advantages and disadvantages of different approaches. International literature sources were identified using targeted keyword searches using Google Scholar in order to capture a broad range of scholarly and technical works. The review then follows with a detailed account of the origin and development of the seminal (German) energy benchmarking methodologies, delivered here for the first time and opening up previously inaccessible literature to an international audience. The review finds that despite its long-term use, disagreement remains regarding the most suitable energy benchmarking performance metrics and there is currently no internationally agreed approach to assess the energy performance of a WWTP. It further highlights that the European approach to energy benchmarking demonstrates that methodical optimisation of WWTPs and application of identified energy saving measures, presents great opportunities to deliver achievable, environmentally- and economically-favourable change to water industry practice. Nevertheless, site-specific factors such as differing discharge conditions, topographical boundary conditions, wastewater volume and composition need to be considered when adapting and applying energy benchmarking methodologies elsewhere, and these factors should be taken into consideration by wastewater practitioners during energy benchmarking assessments.

Keywords: energy benchmarking; energy efficiency; process level optimisation; target and guide value KPIs; wastewater treatment plant.

This is a post-peer-review, pre-copyedit version of an article published in Water Conservation Science and Engineering. The final authenticated version is available online at: http://dx.doi.org/10.1007/s41101-020-00086-6. 


\section{Introduction}

Like many industries during the $20^{\text {th }}$ century, the water sector has evolved considerably from the days of simple 'pipes and pumps' operation, and basic sanitation compliance. During the early years of the $20^{\text {th }}$ century, wastewater management was seen primarily as a water conveyance issue, with the core objective being the quick transport and disposal of wastewater and its contaminants to receiving waterways. Due to the progressive development and implementation of ever more stringent human and environmental health regulations, throughout the second half of the last century in particular, the water industry has largely been focused on meeting and maintaining proper regulatory compliance [2], with less emphasis historically placed on efficiency and innovation in its operations.

The same is largely true of energy use for wastewater treatment. Until recently, energy has been relatively inexpensive internationally and many wastewater treatment facilities were simply not designed or operated with a goal to minimise energy consumption [3]. Moreover, the gradual progression from simple low-cost treatment processes, to more advanced highly engineered processes in order to meet increasingly stringent regulatory criteria has led to a progressive increase in the energy intensity of wastewater treatment over time $[4,5]$. This progressive intensification of energy needs for wastewater treatment has been brought sharply into focus in recent years by dramatic increases in the unit cost of energy, including electricity [6], as well as increasing volatility in energy tariffs linked to deregulation and structural changes to energy markets internationally [7]. In combination, these factors have increased the pressure on energy-intensive industries and facilities like wastewater treatment plants (WWTPs), to look for ways to minimise operational energy use.

In the context of increasing global water scarcity [8], making the most of fresh water resources has become essential in regard to securing supply. Consequently, the recovery and reuse of wastewater is becoming increasingly commonplace in many countries globally [9]. Technologies that make wastewater suitable for immediate and direct-including potablereuse are being introduced, together with regulatory compliance targets requiring increased levels of treatment in order to address public health concerns. Yet increased levels of treatment to produce a high quality effluent comes at a cost, including higher energy use [10], making it imperative to optimize and manage energy use for wastewater treatment and reuse operations to deliver water in an economically-feasible manner.

This is a post-peer-review, pre-copyedit version of an article published in Water Conservation Science and Engineering. The final authenticated version is available online at: http://dx.doi.org/10.1007/s41101-020-00086-6. 


\subsection{Energy efficiency in wastewater treatment}

Studies reporting on energy consumption of WWTP processes date back to the early 1970s [11]. Even then, an awareness existed of the future importance of energy efficiency, with Hernandez (1978) stating that "Energy consumption at WWTPs may, in the future, be a significant input to the decision makers when determining the extent or type of treatment." While energy required for wastewater treatment on a per capita basis is some 10-fold lower than that of domestic water heating for example [12], WWTPs as industrial facilities are typically among the largest single energy users of municipalities [13, 14], presenting important opportunities for energy optimisation and efficiency gains. WWTPs can represent some 15$20 \%$ of the total energy consumption of municipal public structures and facilities, with energy also constituting anywhere from $15-40 \%$ of total WWTP operating costs [14, 15].

Inefficiencies in WWTPs are due to various factors, among others a lack of operator understanding of energy conservation measures $[4,16]$. The recent adoption of 'state-of-theart' but energy-hungry technologies such as membrane bioreactors (MBRs) and UV disinfection has also become more commonplace, in some cases without good justification of the need for such advanced processes [16].

Given the large amount of embedded energy in wastewater (predominantly thermal and chemical energy) [17], WWTPs also present opportunities for energy recovery. In recent years there has been a special focus on energy self-sufficiency of WWTPs, which is achievable and it can be realised via application not only of energy use reduction through optimisation measures, but also through better capture and utilisation of sludge, investigation and application of new trends in energy production (renewables), and by way of new technologies $[15,18-21]$. To improve energy efficiency in the water sector, energy benchmarking emerged from German-speaking Europe during the 1990s and has since been applied internationally with the broad goal of helping the sector identify and adopt best practice efficiency and performance [22, 23]. Despite its long-term use, disagreement remains regarding the most suitable benchmarking performance metrics [24] and there is currently no internationally agreed approach to assess the energy performance of a WWTP.

With the number of studies on WWTP energy efficiency and energy benchmarking growing considerably in recent years (Figure 1), a review on the topic is both timely and informative for the water industry. Furthermore, and with the exception of a few recent publications in English [25, 26], the original (German) benchmarking literature remains largely

This is a post-peer-review, pre-copyedit version of an article published in Water Conservation Science and Engineering. The final authenticated version is available online at: http://dx.doi.org/10.1007/s41101-020-00086-6. 
inaccessible to an international audience, leading to instances where the original methodology has been incorrectly interpreted and applied.

Accordingly, this review begins with an international assessment of WWTP energy benchmarking studies, followed by a detailed account of the original energy benchmarking methodologies from German-speaking Europe since the emergence of the first publication from Switzerland in 1994, through until the first unified German national methodology in 2015 [29]. The historical journey of energy evaluation and benchmarking methodology is presented here to highlight the industry success stories and at the same time, identify issues and specific considerations that need to be given special attention during the application of energy performance and benchmarking assessments. By providing a timely, in-depth assessment of the genesis and evolution of these original energy benchmarking methods, this review opens up a wealth of previously inaccessible but valuable literature to an international industry readership for the financial and environmental benefit of the industry.

Figure 1. Number of articles published since the year 2000 investigating energy performance and energy benchmarking in wastewater treatment processes (data from Google Scholar using combinations of the following keyword search terms: "WWTP", "energy benchmarking", "energy efficiency", "energy performance", "state of the art technology", "wastewater treatment").

\subsection{Approach}

The study used a variety of approaches to select the literature for the review. Firstly, the selection of reference material was based on the inclusion of WWTP energy performance assessment, with performance evaluations needing to refer to either theoretical, statistical or comparative study methodologies. Studies reporting energy performance as a recognised key performance indicator reference value (e.g., electricity consumption as a function of: design capacity or connected population (PExy); treated wastewater volume $\left(\mathrm{m}^{3} \times \mathrm{y}\right)$; or pollution load removed ( $\mathrm{kg}$ COD $\times y)$ ). Another important selection criterion in literature selection was whether international studies had made reference to seminal European methodology. Special attention was paid to how results compared to the Swiss and German performance benchmarks and whether the authors expressed concerns in applying European methodology to other jurisdictions. Google Scholar was used (Figure 1) in order to capture a broad range of both 
scholarly and technical works. With representation from 24 countries and covering more than 16,950 WWTPs in total, the studies included in the review are listed in Table 1.

\section{Energy benchmarking of WWTPs - an international perspective}

Energy efficiency policies have been implemented in some jurisdictions in recent years to improve energy use efficiency by major industry, reduce costs, improve productivity and deliver greenhouse gas emissions abatement (e.g. Australian Energy Efficiency Opportunities Program 2006, and EU Energy Efficiency Directive 2012). To improve energy efficiency in wastewater treatment, energy benchmarking has been applied by many countries, in particular throughout Europe where high electricity tariffs have driven the development of what is considered 'world's best practice' benchmarking methods [28]. Despite the increasing emphasis on WWTP energy efficiency in recent years and widespread application of WWTP energy evaluations and benchmarking, there is currently no unified or internationally-agreed approach for how to conduct energy benchmarking. Energy benchmarking is a sub-set of the broader 'benchmarking' approach which has been applied by the water industry since the early 1990s as a management tool for identifying best practices [22] that nowadays falls under the International Standard ISO 50001:2011 Energy Management Systems [27]. One of the key activities in both ISO 50001 and energy benchmarking involves the undertaking of an initial energy review to establish an energy performance 'baseline'. This baseline is used for performance monitoring and also set improvement targets in relation to future energy performance [27].

This section provides an overview of the energy performance evaluation methods and energy benchmarking methods and metrics used internationally for the assessment of WWTP energy performance, with a summary provided in Table 1. A description of the referenced original benchmarking work from Switzerland and Germany [14, 30-36] are provided in later sections.

In 2000, Balmér [37] evaluated five Nordic WWTPs with different nutrient removal process technologies in order to determine their performance and identified the energy as a major contributor to increased costs [37]. Balmér discusses how the performance should be measured, and argues that measuring the performance per wastewater treatment volume has disadvantages and it should be avoided in favour of relating it to the number of people connected or to the applied load. Kjellén and Andersson [38] assessed the energy efficiency

This is a post-peer-review, pre-copyedit version of an article published in Water Conservation Science and Engineering. The final authenticated version is available online at: http://dx.doi.org/10.1007/s41101-020-00086-6. 
in Swedish WWTPs applying the 1999 German manual of Müller and co-authors [35]. The study using a theoretical calculation approach concluded that Swedish WWTP performance is half that of German WWTPs (i.e. twice as much energy consumed), with $90 \mathrm{kWh} / \mathrm{PExy}$ (medium to small WWTPs), indicating good potential for energy optimisation. In 2007, Jonasson [39] undertook a comparative evaluation of the energy performance of WWTPs with PE $>100,000$ in Sweden versus Austria and found that median electricity use by Swedish WWTPs (42 kWh/PExy) was considerably higher than that of Austrian WWTPs at 23 $\mathrm{kWh} / \mathrm{PE} \times \mathrm{y}$ [39]. This was considered to be due to the long-term use of energy benchmarking in Austria, whereas it was a relatively new initiative in Sweden at that time. Since 2003, the Swedish Water \& Wastewater Association has operated a web-based system, WASS, for the collection and compilation of key data from the Swedish water utilities with the energy performance expressed as kWh/PExy, as one of five key performance indicators (KPIs) [40]. This initiative no doubt contributed to the improvement in Swedish WWTP energy efficiency during the years between the above two studies.

In 1999, an Austrian study was undertaken using the Müller et al. [34] methodology to assess 172 WWTPs representing some 35\% of WWTPs in Austria at the time $(>3,000$ PE capacity) [41]. The wide range of WWTP performance results $(\mathrm{kWh} / \mathrm{PE} \times \mathrm{y})$ revealed great savings potential, with the study reporting that inefficiencies related to unfavorable natural conditions (topography, rainfall dilution of sewage), design issues, equipment performance or a low utilisation rate (equipment over-sizing). In addition to operational optimisation, good planning (utilization of the plant, process concept, adaptability and equipment) was suggested to have a crucial role in energy efficiency.

In Italy, Vaccari et al. [43] used a statistical approach to evaluate the energy performance of 241 WWTPs servicing a combined load of 9.1 million PE. The study measured the specific energy consumption against three performance indicators, expressed as kWh per: $\mathrm{m}^{3}$ wastewater; $\mathrm{PE}$; and $\mathrm{kg} \mathrm{COD}_{5}$ removed. It concluded that one of the factors associated with high energy efficiency was the capacity of utilisation (over $80 \%$ ). This utilisation factor as introduced by LFU BW [33] is expressed as the ratio of connected PE to designed capacity PE (designed value). The utilisation factor is an important indicator when analysing energy saving measures, as it has a considerable impact on capital expenditure, operating expenditure as well as energy performance, but in many cases it is omitted from WWTP energy performance investigations despite its importance.

This is a post-peer-review, pre-copyedit version of an article published in Water Conservation Science and Engineering. The final authenticated version is available online at: http://dx.doi.org/10.1007/s41101-020-00086-6. 
Bodík and Kubaská [44] used a statistical approach to energy benchmark 68 Slovak WWTPs, represented in five class sizes (SCs), reporting a flow-specific performance for 51 large WWTPs (5,000 to 1,050,000 PE designed load capacity, with a total connected capacity of some 2.5 million PE) at $0.485 \mathrm{kWh} / \mathrm{m}^{3}$, with the remaining 17 small rural WWTPs (500 to 2,500 PE designed load capacity, with a total capacity of 15,000 PE) performed at 0.915 $\mathrm{kWh} / \mathrm{m}^{3}$. The approach used in their study compares overall WWTP energy performance and ranks their performance against plant performance, similar to the German methodology [30, 33 ], concluding that the flow-specific energy consumption of the larger plants (10-50 ML/d) is about $50 \%$ less than for smaller plants $(<5 \mathrm{ML} / \mathrm{d})$.

Mamais, Noutsopoulos [45] evaluated 10 WWTPs in Greece (10,000 to 4,000,000 PE capacity) again using a statistical approach similar to that of LFU BW [33]. The study concluded that the annual specific energy consumption for investigated WWTPs ranged from 15 to $86 \mathrm{kWh} / \mathrm{PE} \times \mathrm{y}$, with aeration being the highest energy consuming process in all WWTPs, accounting for $40-75 \%$ of total energy requirements.

A recent French study analysed the energy use (electricity, gas, and fuel oil) efficiency of 7 WWTPs, with the aim being to establish a baseline of energy consumption and identify the main energy consumers in order to prioritise future energy optimisation actions [46]. Although performance was measured as $\mathrm{kWh} / \mathrm{m}^{3}$, the authors - much like Vaccari et al. [43] — advised against flow-specific energy benchmarking. Similar to Mamais et al. [45], the authors also reported aeration to be responsible for the majority of WWTP electricity consumption.

In Portugal, Silva and Rosa [47] used a statistical approach to evaluate the energy use performance of 17 WWTPs, finding that energy represents one of the higher costs of wastewater treatment and is thus a core measure of WWTP performance assessment and optimisation. Shortly after, Brôco and Carvalho [48] undertook an energy use evaluation of more than 800 Portuguese WWTPs. The evaluation found that electrical energy was the single largest operational expense in WWTPs (50\% of operating costs), with a combined use of 219 $\mathrm{GWh} /$ year $\left(\approx 103,000\right.$ t $\left.\mathrm{CO}_{2}\right)$. The authors reported that while improving WWTP energy efficiency is an ongoing challenge due to the differences in technology used among the plants, energy benchmarking is a useful tool for identifying efficiency opportunities and in particular for predicting future energy consumption, especially during refurbishment and the design of new WWTPs.

This is a post-peer-review, pre-copyedit version of an article published in Water Conservation Science and Engineering. The final authenticated version is available online at: http://dx.doi.org/10.1007/s41101-020-00086-6. 
In China, Yang, Siy [49] evaluated the energy performance of 599 WWTPs in order to establish an integrated national energy performance assessment. Average electrical energy consumption of Chinese secondary level treatment WWTPs was $0.290 \mathrm{kWh} / \mathrm{m}^{3}$, highlighting that the treatment technology used, pollutants and the treated volumes played a significant role in energy consumption. According to Zhang and co-authors, in China, electricity consumption constitutes the largest operating expense of 3,508 WWTPs investigated. The total treatment capacity of the 3,508 WWTPs is $1.48 \times 10^{8} \mathrm{~m}^{3} / \mathrm{d}$ and the plants were investigated based on treatment technologies, pollutant removals, operating load and effluent discharge standards. The study identified the biological treatment stage as main energy consumer, accounting for approx. $70 \%$ of total energy consumption, the majority of which related to aeration systems [50]. Further investigations on energy consumption in China have been conducted by a number of authors with sometimes contradictory findings, i.e. an average energy consumption of 0.20 $\mathrm{kWh} / \mathrm{m}^{3}$ (range of 0.12 to $0.38 \mathrm{kWh} / \mathrm{m}^{3}$ ). An investigation on $22 \mathrm{WWTPs}$, suggests that the low energy use in their Chinese WWTPs may be a result of the advanced WWTPs having been newly constructed as well as the low treated wastewater quality requirements in China relative to elsewhere [51].

In Japan, 985 Japanese municipal WWTPs were evaluated by Mizuta and Shimada [52] based on the scale and system configuration energy performance. To conduct benchmarking analysis of electric power consumption, the study classified WWTPs into different SCs, treatment processes and methods and evaluated their performance. The study applied a similar methodology to the German approach $[30,33]$ and concluded that the differences in energy consumption observed were mostly due to the difference in the scale of WWTPs, rather than differences in wastewater treatment process.

Molinos-Senante, Sala-Garrido [53] evaluated 177 Spanish WWTPs with the aim to contribute to measuring their energy efficiency and the economic and environmental consequences for the water sector by delivering a tool using a Data Envelopment Analysis (DEA) model. The study concluded that the plant size and quantity of organic matter removed were significant variables regarding energy performance. Seeking to determine the energy cost effect related to WWTP inefficiencies from ageing-related plant deterioration, CastelletViciano, Hernández-Chover [54] evaluated 322 WWTPs located in the Valencia region of Spain. The study provided information on energy-related cost measured in $\mathrm{kWh} / \mathrm{m}^{3}$ (expressed as $€ / \mathrm{m}^{3}$ treated wastewater) of the facilities and also process performance, concluding that

This is a post-peer-review, pre-copyedit version of an article published in Water Conservation Science and Engineering. The final authenticated version is available online at: http://dx.doi.org/10.1007/s41101-020-00086-6. 
efficiency losses from diffuser blockages in secondary aeration systems over time was largely responsible for loss in process performance and increased energy consumption. Moreover, efficiency losses were more pronounced in smaller WWTPs (treating $<0.75 \mathrm{ML} / \mathrm{d}$ ) than in larger plants, potentially due to larger plants having better maintenance regimes and also by being able to better mask poor performance through energy recovery (cogeneration) systems which only exist at larger facilities.

In the USA, Carlson and Walburger [55] developed 'ENERGY STAR', an energy index for benchmarking WWTP energy performance that enables the comparison of energy consumption of different WWTPs through the use of a scoring system. Energy data for 266 WWTPs were collected and regression analysis used to determine the parameters most highly correlated with energy use $[55,56]$. The ENERGY STAR benchmarking system compares the energy intensity of an individual wastewater facility with similar facilities nationwide using parameter values of average influent flow, average influent and effluent $\mathrm{BOD}_{5}$, design capacity flow rate, presence of fixed film trickle filtration process and nutrient removal process [56, 57].

In the United Kingdom, Belloir et al. [58] reported on a benchmarking investigation of two full-scale WWTPs, with performance benchmarked for electricity use as well as other energy types including chemical, mechanical and manual. The authors concluding that despite the effectiveness of energy benchmarking methodology, there is the need to include additional relevant parameters, such as effluent quality, site operation and plant layout, to allow adequate benchmarking.

\subsection{Swiss energy benchmarking approach}

\subsubsection{General introduction of concept (Swiss context/top-down approach)}

The first known energy efficiency benchmarking study "Energy in WWTP" ("Energie in ARA") was published in 1994 and was conducted on behalf of three Swiss federal agencies: the federal agency for energy (BFE); the federal agency for economy (BfK); and the federal agency for the Environment (BUWAL) [34]. The main focus of the study was to address energy consumption implications related to air quality (air pollution control), greenhouse gas $\left(\mathrm{CO}_{2}\right)$ emissions and the risks associated with power generation station. While the focus of study was on wastewater treatment as one of the single largest municipal energy users, Müller

This is a post-peer-review, pre-copyedit version of an article published in Water Conservation Science and Engineering. The final authenticated version is available online at: http://dx.doi.org/10.1007/s41101-020-00086-6. 
et al. (1994) highlights that municipalities should look at optimisation options for all structures, facilities and machinery in order to deliver lower operational costs and $\mathrm{CO}_{2}$ emissions.

As stated by Müller [59], the energy optimisation should comply with and fulfil three conditions: the effluent quality in the point of discharge shall not be compromised; the operational safety must be guaranteed; and the measures should be economically feasible to ensure that the application of such methodology is sustainable.

To achieve energy use optimisation and influence water sector operations, the Müller et al. (1994) manual set as its primary target to inform the water industry through practical examples about the possibilities that exist in WWTP energy efficiency and process optimisation. This aimed to support the water industry through application of energy-checks and energy-analysis, thus laying the foundation for the realisation of cost-effective energysaving measures (ESMs) [34]. Based on these principles, the 1994 Swiss manual provided the foundation for specialists, engineers and the wastewater industry, to optimise energy consumption in a systematic manner, promote and encourage economic growth, and contribute to environmental improvement [59].

\subsubsection{Benchmarking process in the Swiss context}

During the period when the studied WWTPs were constructed in Switzerland, the energy consumption of wastewater treatment processes was not included in the planning matrix or operator manuals, as energy tariffs were low and as such energy cost savings were not a priority [59]; instead effluent quality was the main driver. However, increasing scientific consensus during the 1980s regarding the role of electricity-derived $\mathrm{CO}_{2}$ emissions on global climate provided the motivation to develop a methodology enabling systematic energy optimisation for WWTPs, but without compromising effluent quality and resulting public and environmental health.

\subsubsection{The first "Energy in WWTP" manual 1994}

The Müller et al. [34] manual addressed a range of issues related to energy optimisation within WWTP boundaries, focusing on the major energy consuming processes. The manual has a technical focus and seeks to extend the specialist knowledge and expertise of process engineers, managers and WWTP operators in energy optimisation methods and measures by providing

This is a post-peer-review, pre-copyedit version of an article published in Water Conservation Science and Engineering. The final authenticated version is available online at: http://dx.doi.org/10.1007/s41101-020-00086-6. 
practical examples. It delivers a practical working tool to be used by engineers, decision makers and operations personnel, with the tool providing a systematic method for undertaking process-level energy checks and analysis. Additionally, it provides information for managers in regard to a general overview of energy-saving measures, the procedures outlining the necessary steps for efficient planning, and provides assistance for experts to make effective decisions about investments related to energy efficiency [34].

To validate energy efficiency optimisation methodology, the manual incorporates a series of data sources:

(1) Statistical data, to create an overall 'feel' regarding the energy consumption situation in Switzerland;

(2) Investigation on a model-plant to enable the theoretical calculation of energy requirements for optimal operating conditions; and

(3) An energy detailed analysis conducted in two WWTPs in Switzerland validating the ESMs and suggested energy saving potential.

\subsubsection{The second round of "Energy in WWTP" 2010}

In 2010, the Müller et al. [34] manual was updated to include recent contributions and introduced new topics, given the advancement of more energy-efficient technologies and new treatment methods developed since publication of the original manual. New aeration techniques incorporated a lowering of the process but incurred substantially higher energy consumption in other pre-and post-aeration processes which needed to be addressed. Since 2008, the cost-reducing electricity feed-in tariff had provided additional financial incentives and further boosts electricity production from digester gas. Due to the increase in energy prices, efforts to implement energy efficiency had also become more important than in the decades before [14].

\subsubsection{Swiss model methodology}

\subsubsection{Statistical information - Energy consumption in WWTPs in} Switzerland.

In the Müller et al. [34] manual, the energy consumption data records of 962 WWTPs were 
listed as statistical data which was produced from BUWAL energy consumption records dating back to 1990. These records generated an overview of WWTP energy use on a national scale providing a basis for creation of an energy performance data-set for further statistical investigation.

To better understand the process-level energy consumption of an energeticallyoptimised WWTP, Müller et al. [34] introduced the concept of a model-plant representing a typical WWTP in Switzerland [14]. The primary function of the model-plant was to establish the theoretical optimum energy performance or so-called "Ideal Values" of the plant as a whole and importantly for its individual processes. The model-plant was used to calculate both specific and absolute energy consumption for each process stage.

In the Müller et al. [14] update, a focus was applied to the new methods/technologies for biological treatment, such as fixed-bed reactor processes, fluid-bed reactor processes, and MBRs. The calculations for the model-plant assume that the machinery and electro technical equipment of the plant are state-of-the-art in relation to energy efficiency. Thus, the energy consumption values of the model-plant can be met for new plants for all process stages [14]. Müller et al. [14] discuss that since values are related to location-specific characteristics (e.g. differing lift station pumping head requirements and wastewater carbon/nitrogen ratios) and despite optimal planning and operation of a WWTP, the ideal values cannot always be achieved.

The energy consumption for the individual process of model-plant was determined mainly by theoretical calculations. In addition to theoretical calculation, judgment values were used based on relevant experience. For all standard procedures, both absolute values for the model-plant and specific values are given for 1 population equivalent. The PE are calculated from the effective annual average $\mathrm{BOD}_{5}$ load to the inlet of the WWTP, on the basis of $60 \mathrm{~g}$ $\mathrm{BOD}_{5}$ / PExd; alternatively, the COD load in the influent (bases on $120 \mathrm{~g}$ COD / PExd) can be used. In addition, the energy consumption is stated per $1 \mathrm{~m}^{3}$ of wastewater or sludge [14].

When comparing the energy consumption performance of WWTPs, they must be related to some common base and in many cases the volume of wastewater treated has been used. However, the use of volumetric (flow-specific) energy performance metrics has recognised disadvantages, including the effects of variable precipitation rates on WWTP inflows which impact on energy cost per $\mathrm{m}^{3}$ treated due to dilution of the pollution load [37, 43]. In such cases, plants with a more dilute wastewater but a higher volumetric load will be

This is a post-peer-review, pre-copyedit version of an article published in Water Conservation Science and Engineering. The final authenticated version is available online at: http://dx.doi.org/10.1007/s41101-020-00086-6. 
shown to perform better and energy inefficiency will not be properly reflected. Also, the range of processes involved in wastewater treatment (for process level investigations) means that the energy performance of some process infrastructure is volume related (e.g. pumps), while energy use is mass flow related for other processes (e.g. aeration and sludge treatment) and others are neither related to volumetric flow nor to mass flow. Considering these complications, Balmér [37] recommends the use of a population equivalent approach wherein energy consumption is related to the number of people connected or to the applied load, enabling better comparisons of energy consumption between different plants with different pollution loads.

Tables 2 to 5 represent the specific energy consumption (Ideal Values) for various wastewater treatment and sludge treatment processes, for infrastructure, and for the entire plant as suggested by Müller at al. [14].

After the identification of energy consumption according to Müller et al. [14, 34] manuals, the water utilities should compare the values to the identified values of the modelplant (ideal values) and work toward how to reduce the energy consumption. Both Müller et al. [34] and Müller et al. [14] manuals stressed that an energy optimisation strategy should include a reduction of energy required for transportation of wastewater in networks and a strategy for replacement of equipment/assets with energy-efficient equivalents. Additionally, all conveying units should be designed accordantly and have intelligent operation. Furthermore, the water utilities should look at minimising support units' energy consumption and look at increasing the energy production within the facility.

\subsubsection{The relevance of energy benchmarking model to planning matrix}

In order to have sensible and realistic benchmarking application it was suggested that the water utilities include benchmarking into a planning matrix by including a systematic approach to energy optimisation. According to Müller at al. [34] energy-checks should be initiated and energy-analysis should be introduced for this purpose. The energy-check is a quick and simple evaluation of the WWTP energy performance, while the aim of the energy-analysis is to identify a set of measures with economic indicators that can be used to assess the financial realisation of efficiency measures and planning of short-term measures. Müller et al. [34] provides a detailed description of all procedures to be followed regarding how and when it is advised to conduct energy-check and energy-analysis.

This is a post-peer-review, pre-copyedit version of an article published in Water Conservation Science and Engineering. The final authenticated version is available online at: http://dx.doi.org/10.1007/s41101-020-00086-6. 
In the initial Phase 1, a coarse initial energy performance screening, is required. This enables an overview of energy consumption with less effort and is the first step toward a systematic energy audit. This initial energy-check is designed to be simple to undertake and provides an overview on the consumption quality of WWTPs whilst identifying the needs and urgency for future ESMs.

After the initial Phase 1, the next intervention for ensuring energy optimisation in WWTPs, a detailed Phase 2 energy-analysis, should be conducted. According to Müller et al. [14], a Phase 2 energy analysis should be completed: after every major refurbishment, renewal and enlargement/extension; if larger energy-saving potential is assumed after conducting energy-check; if the digester gas is only partially used with a cogeneration/turbine; and if one of the assessed ESMs has not yet been met.

In the Phase 2 energy-analysis, the relevant energy saving potential for a WWTP is comprehensively determined across all process areas and the potential savings, cost effectiveness and chronological sequence of the proposed ESMs should be shown.

Achievable ESMs require a calculation of investment costs and benefits (cost effectiveness) which will determine the delineation of ESMs into either immediate measures (I) which are immediately feasible (low investment, no consequential problems), short-term measures (S) which in the course of future rehabilitation/expansion are feasible, and related measures $(\mathrm{R})$ - which in the course of a general remodelling/extension are feasible [14, 34]. According to Müller et al. [14], conducting an energy-analysis should enable the answering of the following questions: Which immediate measures (I) can be realised quickly and with little effort? Are other short-term measures (S) and related measures (R) feasible with reasonable effort? For which further measures is a preliminary project or planning directly useful?

After implementation of any ESM, measuring the success is the final Phase 4 where the energy reduction is recorded and assessed. According to Müller et al. [14] Phase 4 energy assessments can be evaluated through annual energy performance reviews which provide an opportunity to identify further energy savings on an ongoing basis.

\subsection{German model}

By the end of the 20th century, there was increased awareness in Germany of avoided energy use and its relationship to climate change. Some initiatives associated with energy optimisation in WWTPs took place in the early years of the 21st century [59] although it wasn't until more

This is a post-peer-review, pre-copyedit version of an article published in Water Conservation Science and Engineering. The final authenticated version is available online at: http://dx.doi.org/10.1007/s41101-020-00086-6. 
recent years that the demand for energy-efficient processes regained full momentum due to sharp rises in energy prices [60] and also stringent regulation in EU and at the national level, requiring energy efficiency in operation of WWTPs [61-63].

The German approach to energy optimisation in WWTPs is influenced by two different methodologies: the Swiss "Energy in ARA" methodology of [34]; and the 1998 State Institute for the Environment, Measurements and Nature Conservation of Baden-Württemberg (LFU BW) "evaluation of statistical data referring to industry performance" [33].

The application of the Swiss methodology examined a model-plant and addressed accordingly theoretical energy consumption values, suggesting that water utilities should refer to these values when conducting energy optimisation. This approach was well received and, due to its success in Switzerland, in 1999 was replicated in North Rhine-Westphalia (NRW) in Germany [59] and updated in 2017 fulfilling also the requirements as stressed in the 2015 DWA regulations [36]. Meanwhile, in 1998 the German LFU BW introduced a new approach to energy optimisation introducing for the first-time, energy benchmarking for WWTPs. The LFU BW [33] study assessed 1,107 WWTPs in order to determine their overall energy performance and established a common value that WWTPs should aim for in their energy optimisation efforts. In taking a broad-based approach comparing overall energy performance to other plants without the need to conduct detailed energy analyses, this approach offered a uniquely cost-effective way of assessing energy performance, particularly for smaller WWTPs [33]. Based on this approach, the LFU BW methodology determined two reference orientation values: the so-called 'target' and 'guide' values.

In both methodologies, special attention was given to the operators (i.e. human element) as a major factor in influencing WWTP performance outcomes. Nevertheless, an operational manual explaining to plant operators how to run WWTPs to achieve good energy performance did not exist. For this purpose and using the energy performance values of LFU BW [33], Roth and Baumann [64] published the first manual for operators outlining the necessary knowledge and tools for personnel to be able to evaluate WWTP energy efficiency. To reflect progress in data management, treatment technology advances linked to emerging pollutants (e.g. pharmaceuticals, cosmetics and industrial chemicals) [60] and the increased number of WWTPs participating in energy benchmarking, the Roth and Baumann [64] operational manual was updated and republished in 2008 and 2014 [30, 31].

This is a post-peer-review, pre-copyedit version of an article published in Water Conservation Science and Engineering. The final authenticated version is available online at: http://dx.doi.org/10.1007/s41101-020-00086-6. 
Following the rapid change in treatment technology during the 1990s, linked to new effluent quality requirements as specified in the European council directive on urban wastewater treatment (91/271/EEC) [65], and The Water Framework Directive 2000/60/EC (WFD) [62], there was a need to rationalise the treatment performance objectives against energy performance for 'best available techniques'. In 2005, the German Federal Environment Agency commissioned an expert investigation, led by Haberkern, to report on the energy performance of wastewater treatment processes. Based on the Müller [34] methodology, Haberkern et al. [32] reported that while their investigation showed potential for increasing the energy efficiency of wastewater treatment systems, no systematic unified national methodology existed to assess the energy efficiency performance of WWTPs and extensive expertise is then required to implement energy optimisation in practice.

Following the Haberkern et al. [32] findings and referencing Müller et al. [14, 34, 35], LFU BW [33] and Baumann et al. [31], the German Association for Water Management, Wastewater and Waste (DWA) published the first unified national methodology in 2015 for estimating the energy efficiency of wastewater treatment systems [26]. This practice-oriented DWA guideline provides a detailed approach for planners, operators and specialist authorities to undertake energy optimisation of wastewater treatment systems, including energy checks and detailed energy analysis for energy optimisation

\subsubsection{Müller et al. (1999) - Energy in WWTPs, Handbook, NRW}

\subsubsection{The first round of "Energy in WWTP, NRW" 1999}

Following the success of the Energy in ARA manual implementing energy saving measures in Switzerland, the Swiss experts were asked by the Ministry of Environment in North RhineWestphalia to lead the project for formulation a German energy performance manual. These energy performance manuals gained popularity not only in NRW and Germany [66] but were also used as a reference document for many other countries.

The NRW manual of Müller et al. [35] was similar to the Swiss manual, with slight changes in order to reflect the German WWTP conditions and characteristics.

The approach of Müller et al. [35] followed the same principles as per the 1994 Swiss manual. A 1998 survey by the Ministry for the Environment, Regional Planning and Agriculture of all 10,000 PE design capacity WWTPs in NRW was used to formulate a

This is a post-peer-review, pre-copyedit version of an article published in Water Conservation Science and Engineering. The final authenticated version is available online at: http://dx.doi.org/10.1007/s41101-020-00086-6. 
statistical database. With a survey response rate of $89 \%$, some 344 WWTPs were evaluated (one fifth of all WWTPs state-wide).

The model-plant investigation was based on a typical German WWTP, which had been upgraded in accordance with new requirements for nitrogen and phosphorus removal. Plant design was carried out according to the standard design procedures in Germany and it was assumed that state-of-the-art technology was used for the theoretical calculations when referring to energy use. Energy aspects were comprehensively addressed in the operational environment without compromising operational safety or discharge quality requirements [35]; nevertheless, a determination of what best available techniques meant in relation to energy efficiency was not established at that time.

\subsubsection{Pinnekamp et al. (2017) - Energy in WWTPs, Handbook, NRW}

\subsubsection{The second round of "Energy in WWTP, NRW" 2017}

Drawing on energy analyses from recent years and from extensive research and development projects since the original manual, in 2017, the Müller et al. [35] manual was updated to reflect the increased energy efficiency of wastewater systems and to include and address the new sets of standards and procedures (as defined by DWA-A 216 "Energy Check and Energy Analysis - Instruments for Energy Optimization of Sewage Plants"), on how to energetically optimise WWTPs and pumping stations. According to Pinnekamp et al. [36], these new findings required an extensive revision and reissue of the previous manual; although the focus of the new manual remained the same. According to the authors, the goal is no longer energy saving alone, but rather the increase in energy efficiency through a holistic view of energy provision, conversion, storage and consumption as well as their intelligent networking. The manual clarifies that an increase in energy efficiency must always be accompanied by process optimisation.

\subsubsection{LFU BW (1998) approach - Electricity consumption on municipal} WWTPs, Baden-Württemberg

Following on from the Müller et al. [34] manual, in 1998 the State Institute for the LFU BW conducted a study led by Roth, in WWTP energy optimisation potential using a different approach. The LFU BW [33] study was mainly driven by wastewater treatment energy cost,

This is a post-peer-review, pre-copyedit version of an article published in Water Conservation Science and Engineering. The final authenticated version is available online at: http://dx.doi.org/10.1007/s41101-020-00086-6. 
but also considered the broader environmental and socioeconomic concerns associated with energy generation. The study was intended to serve as a reference for the water industry and also for environmental protection administration enabling them to conduct a critical examination when considering energy use and costs involved in WWTPs with reference to the performance values provided [33].

The study comprised a total of 1,107 WWTP survey responses; 397 from Swiss, NRW, Bavaria and Lower Saxony and the remaining 710 from Baden-Württemberg.

The statistical data evaluation was conducted according to five WWTP size categories (SC1 to SC5) as specified by German wastewater ordinance [67, 68]; however, the detailed WWTP survey information provided also allowed for classification of the data according to 12 size classes (SCs) which enabled performance comparisons between the two different size classification systems. Energy performance data were analysed according to the various WWTP SCs (based on design capacity PE) and no consideration was given to process or treatment requirements, or process performance. Referring to LFU BW [33], the most important reference value is the number of connected population equivalents, expressed as the sum of population pollution load in domestic wastewater (served inhabitants) and the measured pollution (organic) load from commercial sources entering a sewage treatment plant. Furthermore, another important factor in evaluation of WWTPs is the utilisation ratio " $f$ ", defined as ratio of connected PE (operational value) and designed capacity PE (designed value). For the specification of wastewater organics and organic load, COD is used instead of BOD, as COD is not only a more defined parameter but is also measured more often by water authorities as part of routine WWTP monitoring.

Energy use performance data across all WWTPs were represented in a number of ways, including annual electricity consumption as a function of design capacity and connected population $(\mathrm{PE} \times \mathrm{y})$, the treated wastewater volume $\left(\mathrm{m}^{3} \times \mathrm{y}\right)$, and the pollution load removed $(\mathrm{kg}$ COD $\times y)$.

The average PE-specific energy consumption in relation to WWTP size was presented, noting that the PE-specific energy consumption decreases as the WWTP increases in size.

To determine the energy use, as a function of biological nutrient removal processes, the data for the different plant sizes were sorted according to five basic processes: aerated lagoons; rotating biological contactors; trickling filters; activated sludge systems with simultaneous aerobic sludge stabilization; and activated sludge systems with separate sludge stabilization.

This is a post-peer-review, pre-copyedit version of an article published in Water Conservation Science and Engineering. The final authenticated version is available online at: http://dx.doi.org/10.1007/s41101-020-00086-6. 
The mapped cumulative frequency curve then enabled the delivery of the specific energy use values for a direct process comparison, but according to LFU BW [33] the specific values are suitable to only a limited extent, since the main focus of the five basic processes are on different installation sizes.

In addition to energy consumption, WWTP energy generation from sludge treatment processes was also accounted for as well as its on-site use (e.g. in digester heating). Energy generation was measured for 160 WWTPs using activated sludge systems, with digester gas power generation presented as percentage of energy self-sufficiency.

In the second part of the study, the energy consumption data for different WWTP processes among the different SCs were sorted according to the following priorities. Firstly, to identify the key areas of fluctuated energy consumption for individual treatment processes (individual consumption points). Secondly, to understand how the 'high' and 'low' electricity consumption performance is achieved. Lastly, to identify which WWTPs/processes have excessive electricity consumption and need further examination. A priority list was established according to the average consumption values (median values), whereby individual consumption points were defined more narrowly.

The LFU BW [33] carried out two separate surveys in order to collect: 1) a detailed breakdown of plant-wide electricity consumption for eight WWTPs, each with different basic biological nutrient removal process configuration and widely divergent energy use performance; 2) additional comparative value by means of a targeted query of the current consumption of individual drives (being operated under the same load continuously or fixed time schedule) on a larger number of other plants. The evaluation of total energy consumption and a rough estimation of energy saving potential were represented as 'guide' and 'target' values for PE-specific energy consumption in WWTPs of different SCs and different biological treatment stages. Target values refer to energy use performance achievable through energyconscious planning and operations, and represent $20^{\text {th }}$ percentile (industry best) performance values. Guide values represent the $50^{\text {th }} \%$ ile median (industry average) energy use performance values

According to LFU BW [33], if a given WWTP's PE-specific energy consumption exceeds the guide value, there is a mid-to-high energy saving potential as referenced against the relevant target value, signalling urgent need for action. In most cases, such energy optimisation can be achieved through operational changes without cost. On the other hand, if

This is a post-peer-review, pre-copyedit version of an article published in Water Conservation Science and Engineering. The final authenticated version is available online at: http://dx.doi.org/10.1007/s41101-020-00086-6. 
WWTP energy use is in the range of the target value, the energy savings potential is considered relatively small; although the potential value of a detailed process-level energy audit should not be ignored.

\subsubsection{Baumann and Roth (1999; 2008) and Baumann et al. (2014) - Reduction} of electricity consumption in WWTPs: Manual for operational personnel

The approach to WWTP energy optimisation of Baumann and co-authors was that where the operation plays a key role in energy efficiency, personnel must first be familiar with WWTP energetics, and then be qualified and motivated to improve operational efficiency. The first manual contributing to educating and engaging operational personnel on WWTP energy efficiency was published in 1999 by Roth and Baumann [64]. Second and third editions were published in 2008 and 2014 respectively to comprehensively revise and update the 1999 version. Together, these manuals provide operational personnel with the necessary information to enable them to evaluate WWTP energy consumption and to tackle opportunities for reducing electricity consumption [31].

While Müller et al. [14] identified the plant-specific ideal values as performance values required for energy optimisation, Baumann et al. [31] excluded the ideal value of Müller and co-authors as necessary in assessing WWTP energy consumption, as its determination is comparatively complex and requires inputs which are often not feasible for operating personnel. In addition to complexities in plant-specific ideal value calculation, these values are also not suitable for comparative purposes. Baumann et al. [31] instead use the PE-specific energy consumption ( $\mathrm{kWh} / \mathrm{PE} \times \mathrm{y})$ as a more suitable performance metric, suggesting an observation period of 1 year for performance data collection.

The PE-specific energy consumption values were represented in the form of guide values (Table 6) and target values (Table 7) and are to be applied according to size and the biological methods of treatment. As these target values are not theoretical values, but are drawn from statistical performance data, Baumann and co-authors suggest that in the face of often difficult operating conditions, target value performance will not be attainable in all existing WWTPs within the context of economically-justifiable efficiency expenses. 
In its 2014 version for determining the target and guide values, Baumann and coauthors used the statistical information for energy performance comparisons of 6,823 WWTPs published by DWA (2012) [31, 69].

Baumann et al. [31] further provide a detailed review on target and guide values for the energy needs of individual consumption points, suggesting that the energy consumption spectrum should be broken down and the relevant energy consumers be considered more closely to identify efficiency weaknesses.

\subsubsection{Haberkern et al. (2008) - Increased energy efficiency in municipal} WWTPS

In 1996, the EU established the Integrated Pollution Prevention and Control (IPPC) directives, with the purpose of applying an integrated approach to pollution control of air, water, and soil pollution privation. In its Article 2 (11) IPPC requires that member states use the 'best available techniques' in addressing pollution prevention. The IPPC defines the 'best available techniques' as the most effective and advanced method of operation with the focus on pollution and emission reduction. The IPPC determines 12 important points of consideration when determining the 'best available techniques', among others "the consumption and nature of raw materials (including water) used in the process and their energy efficiency"[61]. In 2000 the EU established the Water Framework Directive (WFD), a comprehensive policy aimed at the improvement of water quality across the board within the community's boundaries [62]. The WFD readdresses the Article 2 (11) of IPPC under article 10 (2a) restating the importance of using 'best available techniques' in wastewater treatment operations.

In accordance with IPPC and WFD in August 2005, the German Federal Environment Agency launched a project to define state-of-the-art (best available techniques) relating to energy efficiency in WWTPs. This task was assigned to two engineering consultant offices, with the investigation led by Haberkern.

While literature data detailing the current energy efficiency situation at the time was extensive, it was largely from the 1990s; meaning that newer technological developments and trends in energy-efficient wastewater treatment were not systematically considered in standard WWTPs. According to the authors, there was a strong gap between the theoretically possible "optimal" energy consumption values and existing performance, despite numerous prior optimisation efforts in WWTPs, and that, the application of flat-rate target benchmarks for

This is a post-peer-review, pre-copyedit version of an article published in Water Conservation Science and Engineering. The final authenticated version is available online at: http://dx.doi.org/10.1007/s41101-020-00086-6. 
specific energy consumption is not sufficient due to different methodologies and local framework conditions, and may also fail due to site-specific factors such as differing discharge conditions, topographical boundary conditions, wastewater volume and composition, asset management and prolonged lifespan for old plants, etc. As such, a compromise between a uniform definition of the state-of-the-art technology and consideration of local conditions needed to be found.

To fulfil this task while referring to the problematic nature of the issue, a current-state evaluation of WWTPs driven by energy efficiency methodology discrepancies wildly applied in WWTPs was crucial. For this, Haberkern et al. [32] followed a set of procedures starting with an assessment of available statistical data on all processes involved in WWTPs and frequency distribution of these processes to different SCs in order to determine their relevance/importance.

Furthermore, Haberkern and co-authors, presented a description of new techniques (referring to energy manuals which have developed and partially established new techniques, for which no well-founded derivations of parameters were available), and scenarios for future trends and the interactions between energy optimisation and WWTP operation. The study delivered and defined the state-of-the-art, and presented typical approaches, procedures and results of energy optimisation as case studies.

The study was subdivided into four sub-phases, starting with the definition of size class and plant designs for WWTPs. Phase two was concerned with the definition of advanced stateof-the-art technology. The third phase involved a matrix evaluation of target vs. current performance for WWTPs and process steps. Lastly, a final report with documentation of references for the energy optimisation was then prepared, including case studies and methodological notes on the approach to energy optimisation [32].

For new and existing WWTPs, Haberkern and co-authors proposed a triple step procedure in evaluation of energy efficiency. Step I, ensure transparency by recognising the large consumers via separate electricity meters and determine the actual energy value of PE specific energy. Step II, compare the actual energy values with target values and guide values for energy efficiency on the respective SC. And, step 3, determine the short and medium need for action.

According to Haberkern et al. [32], the corresponding target values and guide values are to be applied initially for the larger WWTPs (SC 3 to 5), in order to limit the labour and

This is a post-peer-review, pre-copyedit version of an article published in Water Conservation Science and Engineering. The final authenticated version is available online at: http://dx.doi.org/10.1007/s41101-020-00086-6. 
administrative costs and ensure the proportionality of effort and possible profit. If the guide values are exceeded, it must be demonstrated in each individual case whether an improvement in energy efficiency at a reasonable cost is possible or if special conditions have led to unfavourable values. In this case, Haberkern et al. [32] recommends the conducting of an energy-analysis according to the standards as proposed by Müller and co-authors, with this to be completed within a period of two years.

\subsection{DWA 2015-Regulation for energy check and energy analysis as instruments for energy optimisation of sewage systems.}

The results of previous analyses carried out by the UBA [32], as well as the work conducted in benchmarking of WWTPs in NRW, demonstrated the significant potential for energy efficiency optimisation of wastewater treatment systems. In view of the complex processes involved, a systematic approach for energy optimisation of wastewater treatment systems is essential; however, until recently, there was no nationwide uniform methodology for assessing the energy efficiency of wastewater treatment systems in Germany. In 2015, the DWA published the first regulations which provide much needed mechanisms for energy optimisation in wastewater treatment. The main scope of the regulation includes the delivery of a practice-oriented working instrument for procedural and energy optimisation of wastewater treatment systems to planners, operators and specialist authorities. The regulation introduces energy-checks and energy-analysis as methods for the energy optimisation of wastewater treatment systems and formulates requirements for the use of these methods, including the requirement to compare the current energy status with the plant-specific ideal value for the energy assessment of WWTPs.

The DWA [29] regulation demands the capture and optimisation of energy efficiency be carried out through the performance of an energy check and development of an energy analysis.

\subsubsection{Energy check}

The energy checks are to be carried out annually, and to be understood as a means of energy 'self-assessment' and are designed to be conducted by the WWTP operators. From the results of the energy check, the most obvious performance shortcomings are identifiable, and

This is a post-peer-review, pre-copyedit version of an article published in Water Conservation Science and Engineering. The final authenticated version is available online at: http://dx.doi.org/10.1007/s41101-020-00086-6. 
conclusions can be drawn about the energy strategy development and potential further actions and needs in relation to energy analysis. High quality data and the clear definition of the system limit/coverage are highlighted as particularly important regarding the energy checks.

\subsubsection{Development of a detailed energy analysis}

A detailed survey and evaluation of the energy situation of a WWTP is an integral part of an energy analysis states DWA [29], including a comparison of the costs with the energy savings and operating costs. An energy analysis is appropriate if individual specific values in the energy check reveals potential for optimisation or are subject to a negative development over time. In the energy analysis, the elements of the energy check are expanded, demanding firstly a systematic, detailed survey of the energy requirement in relation to equipment, equipment units and/or plant components within an energy balance. Secondly, an assessment of the energy situation by comparing the actual values with plant-related ideal-values as identified by Müller at al. [14], and thirdly, a presentation of concrete measures for energy optimisation with a comparison of the cost-frame reflecting energy and operating costs. Plant-related idealvalues are used to describe an optimum range of energy inputs. They are calculated for an optimum mode of operation within the framework of the energy analysis and take account of structural or process-related boundary conditions, which are virtually unchangeable or cannot be altered with economically-justifiable effort [26].

\section{Summary, recommendations and future challenges in WWTP energy benchmarking}

The European approach to energy benchmarking has proven that methodical optimisation of WWTPs and application of ESMs present a great opportunity to demonstrate achievable environmentally-focused and economically-feasible change in the water industry. Nevertheless, site-specific factors such as differing discharge conditions, topographical boundary conditions, wastewater volume and composition need to be considered when adapting benchmarking methodologies and KPIs elsewhere. A number of key challenges and considerations for the future of WWTP energy benchmarking internationally have emerged from this review and are outlined below.

This is a post-peer-review, pre-copyedit version of an article published in Water Conservation Science and Engineering. The final authenticated version is available online at: http://dx.doi.org/10.1007/s41101-020-00086-6. 
Regional climate-specific characteristics, as well as the local wastewater quality discharge requirement implications, will have a significant influence on WWTP energy performance. Therefore region-specific energy performance benchmarks that take such specifics into account will offer the best approach in future energy benchmarking efforts internationally.

The application of guide and target value energy performance benchmarks is a costeffective, economically-feasible method to facilitate WWTPs in future optimisation efforts, as this approach enables operators to identify whether their performance sits within the majority of WWTPs with similar characteristics, and if not, identify where improvement is needed. When large discrepancies in energy performance are identified, WWTP operators should further evaluate the appropriate method to conduct an energy analysis, referring to [14], to further identify the opportunities for optimization, with special attention given to process level optimisation. Since operational personnel have a crucial role in achieving WWTP energy performance improvements, consistent energy performance training and recognition of their progressive involvement must be prioritised by water authority planners and decision makers.

Special attention should be paid to the fact that broad industry participation is a critical element to benchmark development, as performance benchmark values of industry performance based on statistical data are only relevant as comparative KPIs for water utilities where they have been derived from a sufficiently broad base. A consistent update of energy benchmarks through periodically conducting energy checks referring to WWTP performance based on statistical data, will also ensure that outdated technology and new technologies will be appropriately integrated and industry performance adequately reflected in new energy performances KPI values. In this regard, energy benchmarking initiatives driven by environmental concerns (emissions reduction) linked to state/national government policy, as well as cost-saving imperatives at a utility level, will provide the best overarching framework for the water industry to optimise WWTPs, conserve energy and keep costs low for their customers.

\subsection{Selection of technology in relation to energy performance}

One of many factors that will influence the energy performance will be the use of technologies used in wastewater treatment, often required and defined as 'state-of-the-art'. Nevertheless, uniform definition of 'state-of-the-art' technology in terms of energy efficiency is challenging, 26

This is a post-peer-review, pre-copyedit version of an article published in Water Conservation Science and Engineering. The final authenticated version is available online at: http://dx.doi.org/10.1007/s41101-020-00086-6. 
given the diversity of treatment systems and process techniques used globally and the different operating constraints imposed. Several factors first need clarification, including: the choice of suitable criteria and benchmarks for energy efficiency; the comparability of different processes (plant designs and sizes for wastewater treatment); consideration of important (external) factors (such as topography; treatment performance requirements from an effluent quality perspective, etc.).

\subsection{Choosing the right comparative criteria and KPIs}

A large number of parameters and variables are used in the technical literature on WWTP energy efficiency, including different energy sources and energy consumptions based on different reference values and time periods. When considering suitable criteria and benchmarks for energy efficiency, several factors first need clarification, including: the choice of suitable criteria and benchmarks for energy efficiency; the comparability of different processes (plant designs and sizes for wastewater treatment); consideration of important (external) factors (such as topography; treatment performance requirements from an effluent quality perspective, etc.). Other key considerations include: good availability of comparative data in the literature; ease of determination at the WWTP and simple application for operating personnel; sufficient accuracy of conventional measurement methods; high significance for the energy efficiency of the relevant processes; good comparability of different technologies; and minimising the number of measured variables and criteria [32].

Regarding benchmark KPIs, Longo et al. [24] suggest that no single KPI for characterisation of WWTP energy performance is universally suitable, due to the variability in treatment technology use and plant layout, plant size and location (country, topography) and in wastewater characteristics. Literature consensus is now recommending against use of the indicator $\mathrm{kWh} / \mathrm{m}^{3}$ which does not adequately reflect WWTP function and is easily distorted by stormwater-related sewage dilution, recommending instead the indicator $\mathrm{kWh} / \mathrm{PE} \times \mathrm{y}$ as a more meaningful metric. KPIs which benchmark performance against pollutant removed (organics or nutrients) have recently been suggested as a more sensible metric, since they more closely reflect the function of a WWTP and better align with treatment process-related energy consumption [24]. Integrated KPIs which include all the key pollutants (TSS, COD, N and P) in a single metric have also been proposed, wherein overall WWTP pollution removal (in $\mathrm{kg}$ of 'pollution units') is calculated by a weighted sum of the constituent compounds (see [24]

This is a post-peer-review, pre-copyedit version of an article published in Water Conservation Science and Engineering. The final authenticated version is available online at: http://dx.doi.org/10.1007/s41101-020-00086-6. 
for an in-depth discussion). Future changes to regulated effluent wastewater quality requirements will also serve to increase energy demands from more advanced treatment and disinfection processes at WWTPs (e.g. for removal of micropollutants and antibiotic resistance carriers) [26]. Such changes may call for new benchmark KPIs to ensure proper reflection of WWTP function during energy benchmarking activities and this is suggested as an area for future development in energy benchmarking methodology.

\subsection{Comparison of different processes and size classes}

Recognising that two WWTPs are rarely the same and incoming wastewater qualities are often highly variable, to achieve comparability of energy efficiency assessments it is necessary to clarify which differences are relevant for energy consumption and where differences can be ignored. Therefore, the definition of few standard procedures should be sufficient for a first comparison, as prior determined by Müller et al. [34] methodology. In addition, of course, important assumptions and the system limits are established, and if (in individual cases), severe deviations are noticed, then a detailed analysis would be necessary to determine to whether the deviation are due to boundary conditions are can be influenced by other factors [14, 31, 32].

\subsection{External factors}

External factors can have a huge impact on WWTP specific energy requirements (i.e. topography, rainfall dilution of sewage, variable $\mathrm{BOD}_{5}: \mathrm{N}$ ratios due to industrial wastewater or pre-decomposition in the sewer network, situation-specific requirements for odour control, etc.) (Haberkern et al., 2008). As per Belloir et al. [58], the Swiss, German and Austrian methodologies have limitations related to the need to compare similar wastewater influent pollutant loads, and effluent quality requirements/regulations, as well as $\mathrm{C}: \mathrm{N}$ ratios that are usually different in different geographical regions and impact the comparisons. In such cases it is also necessary to investigate and determine the extent to which these external boundary conditions can be influenced. If in individual cases there are strong deviations from the underlying assumptions of benchmarking approaches, the detailed analysis, as per Müller et al. [14], will be able to establish the extent to which this affects performance and subsequent increases in the target values are required.

This is a post-peer-review, pre-copyedit version of an article published in Water Conservation Science and Engineering. The final authenticated version is available online at: http://dx.doi.org/10.1007/s41101-020-00086-6. 


\subsection{Establishment of best energy efficiency benchmarks/KPIs}

Different possibilities are available in the literature when referring to best energy efficiency benchmark values as already detailed in this review:

- The derivation of parameters from a model-plant with the standard dimensioning and optimal design in accordance with the procedures in existing manuals [14, 32];

- The guide and target values for specific energy consumption, empirically derived from frequency distributions [33];

- Best Practice Principle, the best-known value from practice as a target/optimum is defined for individual plant sections or entire WWTPs;

- The definition of technical-standards (such as occupancy density of diffusers, oxygen efficiency, impeller type / efficiency pumps) [26, 32].

For determination of best energy efficiency values, Haberkern et al. [32] argues that, it is not necessary to choose a pragmatic, therefore empirical approach (from the statistical analysis of energy consumption), which however, can be assured (or modified) by theoretical considerations. The derivation of target values from frequency distributions alone entails the risk that the old state-of-the-art is reproduced. This also applies to model-plants where technically outdated design approaches (e.g. for oxygen consumption) are used or improvements in the efficiency of the aggregates (e.g. for aerator elements, new pump types or centrifuges, etc.) are not taken into account. It is therefore sensible to derive an optimum on the basis of realistic, optimised design and the use of energy-efficient units.

In addition, guide values can be derived from the cumulative frequencies of the specific energy consumption, which allow an initial containment of the plants with potential need for action. Exceedance of the guide value does not necessarily mean that an energy optimisation is urgent or economically feasible, but rather the need for action in these cases should be examined primarily through a detailed energy analysis.

DWA [29] recognises the need for transparency in the benchmarking process, as well as the need to account for technological advancement and progressive development of more stringent effluent quality targets, related for instance to micropollutants/pharmaceuticals which demand more advanced treatment processes with increased energy consumption. Therefore, DWA [29] demands the capture and optimisation of energy efficiency through the performance

This is a post-peer-review, pre-copyedit version of an article published in Water Conservation Science and Engineering. The final authenticated version is available online at: http://dx.doi.org/10.1007/s41101-020-00086-6. 
of an annual energy check and detailed energy analysis where individual specific performance values in the energy check reveals potential for optimisation. This will enable continuous correction of recorded energy consumption values which will be then reflected in new and updated industry performance benchmarks.

\subsection{Future advanced technologies and benchmarking implications}

Successful application of advanced technologies inventions should always be considered especially when WWTPs require upgrades and refurbishment. For instance the Nereda® aerobic granular biomass process from the Netherlands [71] has changed the way we have traditionally thought about WWTP design and operation [72]. By selecting for a larger granular biomass instead of conventional microbial flocs, various biological processes can simultaneously take place within the granule, reducing pumping and mixing requirements and eliminating the need for secondary sedimentation tanks, resulting in more compact and energy efficient WWTPs [73, 74]. Innovations in so-called 'shortcut biological nitrogen removal' processes, such as deammonification (partial nitritation-anammox) and nitritationdenitritation (nitrite shunt), offer considerable future potential for energy savings from avoided aeration requirements, combined with the possibility of enhanced energy (biogas) recovery from reduced organic carbon demands and lower waste biological sludge production $[75,76]$.

While the future looks promising for energy-neutral or even energy-positive WWTPs, it is still early days for the above technologies in practice and there are relatively few examples of their use at full-scale and in mainstream operations [73, 77]. Nevertheless, energy benchmarking methodology and performance KPIs must keep pace with the changing WWTP technology landscape in order to remain relevant and doing so will ensure that it remains a valuable tool for industry to achieve energy efficient wastewater treatment operations in the years ahead. With the increasing use of online instrumentation and real-time monitoring of wastewater treatment operations, there will also be an increasing potential to move toward real-time energy performance assessments via daily benchmarking [78]; however, further improvements in process monitoring and real-time data availability are needed before daily benchmarking can become a reality. Even in a future where WWTPs are routinely energy-neutral, we believe that WWTP energy efficiency will still be important for municipalities from an energy productivity and energy security perspective, especially as economies transition toward (intermittent)

This is a post-peer-review, pre-copyedit version of an article published in Water Conservation Science and Engineering. The final authenticated version is available online at: http://dx.doi.org/10.1007/s41101-020-00086-6. 
renewable energy supplies.

\section{Acknowledgements}

This research was funded by the CRC for Low Carbon Living Ltd. (grant RP2017) whose

activities are supported by the Cooperative Research Centres program, an Australian Government initiative. 


\section{References}

1. Krampe, J. and H. Trautvetter, Energy benchmarking of SA Water's WWTPs. 2012, SA Water Corporation.

2. Hahn, H.H., Water treatment requirements through the years (exemplified by the development in Germany), in David Jenkins and Jiři Wanner (eds), Water treatment Activate sludge - 100 years and counting: 100 years and counting 2014, London, UK: IWA Publishing.

3. NYSERDA, Water \& wastewater energy management: best practices handbook. 2010, New York State Energy Research and Development Authority and Malcolm Pirnie, Inc.

4. Chang, Y., et al., Evaluation of dynamic energy consumption of advanced water and wastewater treatment technologies. 2008: Awwa Research Foundation (AwwaRF). ISBN: 978-1-60573-033-2.

5. Monteith, H., Y. Kalogo, and N. Louzeiro, Achieving stringent effluent limits takes a lot of energy! 2007: In: Proceedings of WEFTEC ${ }^{\circ} 2007$ - the 80th Annual Technical Exhibition and Conference of the Water Environment Federation, San Diego, CA, October 13-17; pp 43434356.

6. AEMO. National electricity market, electricity, average price tables, data dashboard. 201620 April 2019 [cited 201815 August 2018]; Available from:

http://www.aemo.com.au/Electricity/Data/Price-and-Demand/Average-Price-Tables.

7. Escribano, A., J. Ignacio Peña, and P. Villaplana, Modelling Electricity Prices: International Evidence. Oxford Bulletin of Economics and Statistics, 2011(73): p. 622-650.

8. Degefu, D.M., et al., Mapping monthly water scarcity in global transboundary basins at country-basin mesh based spatial resolution. Scientific Reports, 2018. 8(1): p. 2144.

9. Lazarova, V. and T. Asano, Milestones in water reuse: main challenges, keys to success and trends of development. An overview, in Valentina Lazarova, Takashi Asano, Akiça Bahri and John Anderson (eds), Milestones in Water Reuse: The Best Success Stories. 2013: IWA Publishing, London, UK. ISBN: 9781780400716.

10. Meda, A., et al., eds. Energy and water: relations and recoverypotential, in Valentina Lazarova, Kwang-Ho Choo and Peter Cornel (eds), Water-Energy Interactions in Water Reuse. 2012, IWA Publishing, London, UK. ISBN: 9781843395416. 360.

11. Hernandez, D.J., Energy consumption of advanced wastewater treatment at Ely, Minnesota. 1978, U.S. EPA Office of Research and Development, Environmental Rresearch Laboratory, Corvallis, Oregon, 97330. EPA-600/7-78-001, January 1978.

12. Kenway, S.J., et al., A systemic framework and analysis of urban water energy. Environmental Modelling \& Software, 2015. 73: p. 272-285.

13. Krampe, J., Energy benchmarking of South Australian WWTPs. Water Science \& Technology, 2013. 67(9): p. 2059-2066.

14. Müller, E., et al., Handbuch Energie in ARA : Leitfaden zur Energieoptimierung auf Abwasserreinigungsanlagen (Manual, energy in WWTP: Guide to energy optimization on wastewater treatment plants). 2010.

15. Gu, Y., et al., The feasibility and challenges of energy self-sufficient wastewater treatment plants. Applied Energy, 2017. 204: p. 1463-1475.

16. Ragazzo, P., et al., Management optimisation and technologies application: a right approach to balance energy saving needs and process goals, $n$ Katerina Stamatelatou and Konstantinos P. Tsagarakis (eds), Sewage treatment plants: Economic evaluation of innovative technologies for energy efficiency. 2015, London, UK, ISBN: 781780405018 IWA Publishing.

17. Tarallo, S., Utilities of the Future Energy Findings. 2014, London, UK. ISBN: 9781780406800 : IWA Publishing, co-published by Water Environment Research Foundation, Alexandria, Virginia, US.

This is a post-peer-review, pre-copyedit version of an article published in Water Conservation Science and Engineering. The final authenticated version is available online at: http://dx.doi.org/10.1007/s41101-020-00086-6. 
18. Chatzisymeon, E., Reducing the energy demands of wastewater treatment through energy recovery', in Katerina Stamatelatou and Konstantinos P. Tsagarakis (eds), Sewage Treatment Plants: Economic Evaluation of Innovative Technologies for Energy Efficiency. 2015, London, UK, ISBN: 9781780405018 IWA Publishing.

19. Gu, Y., et al., Energy Self-sufficient Wastewater Treatment Plants: Feasibilities and Challenges. Energy Procedia, 2017. 105: p. 3741-3751.

20. Tarallo, S., et al., A Guide to Net-Zero Energy Solutions for Water Resource Recovery Facilities. 2015, London, UK, ISBN: 9781780407685: IWA Publishing.

21. Tarallo, S., et al., Demonstrated energy neutrality leadership : a study of five champions of change. 2015, London, UK, ISBN: 9781780407456: IWA Publishing co-published by Water Environment Research Foundation.

22. Bertzbach, F. and T. Franz, The worldwide search for best practices by benchmarking programmes of the water sector. Korrespondenz Abwasser, Abfall · International Special Edition 2016/2017, 2017.

23. Cabrera, E., et al., Benchmarking Water Services: Guiding water utilities to excellence. 2011, IWA Publishing: Co-published by IWA Publishing, London, UK and American Water Works Association, Denver, Colorado, USA. ISBN: 1843391988.

24. Longo, S., et al., Monitoring and diagnosis of energy consumption in wastewater treatment plants. A state of the art and proposals for improvement. Applied Energy, 2016. 179: $p$. 1251-1268.

25. Baumann, P., et al., Operational problems in wastewater treatment plants, handbook for the operation of wastewater treatment plants, practice guideline troubleshooting and correction of operational problems. 2012, DWA Landesverband Baden-Württemberg.

26. DWA, DWA-Regelwerk, Arbeitsblatt DWA-A 216, Energiecheck und Energieanalyse Instrumente zur Energieoptimierung von Abwasseranlagen (Standard DWA-A 216E DWA Set of Rules, Energy Check and Energy Analysis - Instruments to Optimise the Energy Usage of Wastewater Systems). 2015, DWA Deutsche Vereinigung für Wasserwirtschaft, Abwasser und Abfall e. V.: Hennef. p. 68.

27. ISO, Energy management systems - Requirements with guidance for use. International Organization for Standardization. ISO 50001:2011(E). 2011, International Organization for Standardization: Geneva, Switzerland.

28. Crawford, G.V., Best practices for sustainable wastewater treatment: Initial case study incorporating european experience and evaluation tool concept. 2010: Water Environment Research Foundation, USA and IWA Publishing, UK. ISBN: 9781843393917.

29. DWA, Standard DWA-A 216E DWA Set of Rules, Energy Check and Energy Analysis Instruments to Optimise the Energy Usage of Wastewater Systems. 2015, German Association for Water, Wastewater and Waste (DWA): Hennef.

30. Baumann, P. and M. Roth, Senkung des Stromverbrauchs auf Kläranlagen, Leitfaden für das Betriebspersonal, (Reduction of electricity consumption on wastewater treatment plants, guide for the operating personnel). 2008, DWA Landesverband Baden-Württemberg.

31. Baumann, P., P. Maurer, and M. Roth, Handbuch für den Betrieb von Kläranlagen - Senkung des Stromverbrauches auf Kläranlagen - Heft 4, (Handbook for the operation of wastewater treatment plants - Reduction of electricity consumption at wastewater treatment plants ). 2014, Stuttgard: DWA Landesverband Baden-Württemberg.

32. Haberkern, B., W. Maier, and U. Schneider, Steigerung der Energieeffizienz auf kommunalen Klaeranlagen (Enhanced energy efficiency in waste water treatment plants). 2008: DessauRoßlau

33. LfU BW, Stromverbrauch auf kommunalen Kläranlagen, Handbuch Wasser 4, (Electricity consumption on municipal WWTPs, manual water 4) (In German). Vol. 13. 1998: Landesamt für Umweltschutz Baden-Württemberg (LfU).

This is a post-peer-review, pre-copyedit version of an article published in Water Conservation Science and Engineering. The final authenticated version is available online at: http://dx.doi.org/10.1007/s41101-020-00086-6. 
34. Müller, E., R. Thommen, and P. Stähli, Handbuch, Energie in ARA, Energiesparmassnahmen in Abwasserreinigungsanlagen (Manual, energy in WWTP, energy saving measures in wastewater treatment plants) (in German). 1994.

35. Müller, E., et al., Handbuch, Energie in Kläranlagen, Ministerium fuer Umwelt, (Handbook, energy in WWTPs) (in German). 1999: Raumordnung und Landwirtschaft des Landes Nordrhein-Westfalen

36. Pinnekamp, J., et al., Energie in Abwasseranlagen, Handbuch NRW. 2. vollständig überarbeitete Fassung, (Energy in WWTPs, handbook NRW. 2. completely revised version) (in German). 2017, Düsseldorf: Ministerium für Umwelt, Landwirtschaft, Natur- und Verbraucherschutz des Landes Nordrhein-Westfalen.

37. Balmér, P., Operation costs and consumption of resources at Nordic nutrient removal plants. Water Science and Technology, 2000. 41(9): p. 273-279.

38. Kjellén, B.J. and A.C. Andersson, Energihandbok för avloppsreningsverk, VA-Forsk report $n r$ 2002-2, (Energy handbook for wastewater treatment plants, VA-Forsk Report No. 2002-2) (in Swedish). 2002, Stockholm, Sweden: Swedish Water and Wastewater Association.

39. Jonasson, M., Energy benchmark for wastewater treatment processes - a comparison between Sweden and Austria, in Department of Industrial Electrical Engineering and Automation. 2007, Lund University, Sweden. p. 68.

40. Balmér, P. and D. Hellström, Performance indicators for wastewater treatment plants. Water Science \& Technology, 2012. 65(7): p. 1304-1310.

41. Agis, H., Energieoptimierung von Kläranlagen, Pilotprojekt, Detailuntersuchung von 21 Anlagen, Endbericht Teil A, im Auftrag von und für Bundesministerium für Land- $u$. Forstwirtschaft, Umwelt u. Wasserwirtschaft und Kommunalkredit Austria AG, (Energy optimization of WWTPs, pilot project, detailed investigation of 21 plants, final report Part A, on behalf of and for Federal Ministry of Agriculture and Natural Resources, Forestry, Environment and Water Management, and Kommunalkredit Austria AG) 2001: Vienna.

42. Haslinger, J., S. Lindtner, and J. Krampe, Operating costs and energy demand of wastewater treatment plants in Austria: benchmarking results of the last 10 years. Water Science \& Technology, 2016. 74(11).

43. Vaccari, M., P. Foladori, and F. Vitali, Benchmarking of energy consumption in municipal wastewater treatment plants - a survey of over 200 plants in Italy. Water Science \& Technology, 2018. 77 (9): p. 2242-2252.

44. Bodík, I. and M. Kubaská, Energy and sustainability of operation of a wastewater treatment plant. 2013. 39(2): p. 15-24.

45. Mamais, D., et al., Wastewater treatment process impact on energy savings and greenhouse gas emissions. Water Science \& Technology, 2015. 71(2): p. 303-308.

46. Azimi, S. and V. Rocher, Energy consumption reduction in a waste water treatment plant. Water Practice \& Technology, 2017. 12(1): p. 104-116.

47. Silva, C. and M.J. Rosa, Energy performance indicators of wastewater treatment: a field study with 17 Portuguese plants. Water Science \& Technology, 2015. 72(4).

48. Brôco, N. and N. Carvalho, Management tool to assess, benchmark and support energy efficiency actions in more than 800 WWTP. Water Practice \& Technology, 2017. 12(3): p. 745-749.

49. Yang, L., et al., Operational energy performance assessment system of municipal wastewater treatment plants. Water Science \& Technology, 2010. 62(6): p. 1361-1370.

50. Zhang, Q.H., et al., Current status of urban wastewater treatment plants in China. Environment International, 2016. 92-93: p. 11-22.

51. Li, W., L. Li, and G. Qiu, Energy consumption and economic cost of typical wastewater treatment systems in Shenzhen, China. Journal of Cleaner Production, 2017. 163: p. S374S378.

This is a post-peer-review, pre-copyedit version of an article published in Water Conservation Science and Engineering. The final authenticated version is available online at: http://dx.doi.org/10.1007/s41101-020-00086-6. 
52. Mizuta, K. and M. Shimada, Benchmarking energy consumption in municipal wastewater treatment plants in Japan. Water Science \& Technology, 2010. 62(10): p. 2256-2262.

53. Molinos-Senante, M., R. Sala-Garrido, and F. Hernández-Sancho, Development and application of the Hicks-Moorsteen productivity index for the total factor productivity assessment of wastewater treatment plants. Journal of Cleaner Production, 2016. 112: $p$. 3116-3123.

54. Castellet-Viciano, L., V. Hernández-Chover, and F. Hernández-Sancho, Modelling the energy costs of the wastewater treatment process: The influence of the aging factor. Science of The Total Environment, 2018. 625: p. 363-372.

55. Carlson, S.W. and A. Walburger, Energy index development for benchmarking water and wastewater utilities. 2007, Awwa Research Foundation Report, New York State Energy Research and Development Authority (NYSERDA) Report Number 07-08, 1P-5C-9120112/07-NH.

56. Ast, T., et al., 'Benchmarking wastewater facility energy performance using energy star portfolio manager'. 2008(8): p. 7322-7339.

57. US EPA, ENERGY STAR score for wastewater treatment plants in the United States. 2018, ENERGY STAR: US.

58. Belloir, C., C. Stanford, and A. Soares, Energy benchmarking in wastewater treatment plants: the importance of site operation and layout. Environmental Technology, 2014. 36(2): p. 260269.

59. Müller, E., Energie in ARA: 10 Jahre Erfahrungen - Stand und Ausblick (Energy in WWTP: 10 years of experience - status and outlook) (In German), in Article de Fond. 2004, GWA.

60. Scheuer, L., et al., Profile of the german water sector 2015. 2015: Bonn.

61. EU, Council Directive 96/61/EC concerning integrated pollution prevention and control (of 24 September 1996), in Official Journal of the European Communities. 1996. p. L 257/26 $257 / 40$.

62. EU, Directive 2000/60/EEC of the European Parliament and of the Council, establishing a framework for community action in the field of water policy (of 23 October 2000), in Official Journal of the European Communities. 2000. p. L 327/1-327/71.

63. WHG, Gesetz Zur Ordnung Des Wasserhaushalts, Wasserhaushaltsgesetz In Der Fassung Der Bekanntmachung Vom 19. August 2002 (Bgbl. I S. 3245), Zuletzt Geändert Durch Artikel 2 Des Gesetzes Vom 10. Mai 2007 (Bgbl. I S. 666) [To the order of the water household, water resources act in the version of the announcement from 19 August 2002 (Federal Law Gazette IS. 3245), last modified by article 2 of the law from 10 may 2007 (Federal Law Gazette IS. 666). 2007.

64. Roth, M. and P. Baumann, Senkung des Stromverbrauchs auf Kläranlagen: Leitfaden für das Betriebspersonal, (Reduction of power consumption on WWTPs: Guide for the operating personnel) (in German). 1999: ATV, Landesgruppe Baden-Württemberg.

65. EU, Council Directive of 21 May 1991, concerning urban waste water treatment (91/271/EEC). Official Journal of the European Communities, 1991(L 135/40).

66. Müller, E., et al., Energie in Infrastrukturanlagen - Jahresbericht 2003 (Energy in Infrastructure Installations - Annual Report 2003) (in German). 2004.

67. AbwV, Verordnung über Anforderungen an das Einleiten von Abwasser in Gewässer (Abwasserverordnung - AbwV) (Regulation on the requirements for the discharge of waste water into watercourses (Waste Water Ordinance - AbwV)), W.W.O.-. AbwV, Editor. 1997.

68. FMENCNS, Promulgation of the new version of the ordinance on requirements for the discharge of waste water into waters, federal ministry for the environment, nature conservation and nuclear safety, Germany. 2004, Federal Minister for the Environment, Nature Conservation and Nuclear Safety (BMU).

This is a post-peer-review, pre-copyedit version of an article published in Water Conservation Science and Engineering. The final authenticated version is available online at: http://dx.doi.org/10.1007/s41101-020-00086-6. 
69. DWA, 25. Leistungsvergleich kommunaler Kläranlagen, Reinigungsverfahren auf dem Prüfstand (25. Performance comparison of WWTPs, treatment processes on the test stand). 2012, DWA Deutsche Vereinigung für Wasserwirtschaft, Abwasser und Abfall e. V.: Hennef.

70. Panepinto, D., et al., Evaluation of the energy efficiency of a large wastewater treatment plant in Italy. Applied Energy, 2016. 161: p. 404-411.

71. RHDHV, The natural way of treating wastewater. 2013, Royal Haskoning DHV: Amersfoort, Netherlands.

72. Watson, A., An Operator's Perspective; The First Nereda ${ }^{\circledR}$ Wwtp In Kingaroy, Australia. 2017, Royal Haskoning DHV: Australia.

73. Bengtsson, S., et al., Treatment of municipal wastewater with aerobic granular sludge. Critical Reviews in Environmental Science and Technology, 2018. 48 (2): p. 119-166.

74. Giesen, A. and M. van Loosdrecht, Aerobic granular biomass technology: recent performance data and lessons learnt, in IWA. 2016.

75. Kartal, B., J.G. Kuenen, and M.C.M. van Loosdrecht, Engineering. Sewage treatment with anammox. Science (New York, N.Y.), 2010. 328(5979): p. 702-703.

76. WEF, Shortcut nitrogen removal-nitrite shunt and deammonification. 2015, Alexandria, USA, ISBN: 9781572783133: Water Environment Federation and Water Environment Research Foundation.

77. Yang, F., J.A. Kozak, and H. Zhang, Shortcut biological nitrogen removal methodologies: Mainstream partial nitritation/deammonification and nitritation/denitritation: A literature review. 2014: Chicago, Illinois, US.

78. Torregrossa, D., et al., Energy saving in WWTP: Daily benchmarking under uncertainty and data availability limitations. Environmental Research, 2016. 148: p. 330-337.

79. GHD, Water services association of australia, WWTP energy efficiency benchmarking, Part 2 - technical report. 2014b.

80. GHD, WWTP Energy Efficiency Benchmarking, Part 1 - Summary Report. 2014a.

81. De Haas, D., et al., Benchmarking energy use for wastewater treatment plants. 2017.

82. Soares, R.B., et al., Comparative Analysis of the Energy Consumption of Different Wastewater Treatment Plants. 2017.

83. Blais J, et al., Les mesures d'efficacité énergétique électrique dans le secteur de l'eau, Volume 3. [Measurements of electrical energy efficiency in the water sector, Volume 3], vol. 3. Institut national de la recherche scientifique, INRS-Eau, Rapport scientifique No. 405 [National Institute for scientific research, INRS-Eau, Scientific report No. 405] (In French). Available at:Available from: <http://espace.inrs.ca/1233/1/R000405v5.pdf> [accessed May, 2018]. 1994.

84. Molinos-Senante, M., R. Sala-Garrido, and A. Iftimi, Energy intensity modeling for wastewater treatment technologies. Science of The Total Environment, 2018. 630: p. 15651572.

85. Wang, H., et al., Comparative analysis of energy intensity and carbon emissions in wastewater treatment in USA, Germany, China and South Africa. Applied Energy, 2016. 184: p. 873-881.

86. Patziger, M., Efficiency and development strategies of medium-sized wastewater treatment plants in central and eastern europe: Results of a long-term investigation program in hungary. Journal of Environmental Engineering, 2017. 143(6).

87. Singh, P., C. Carliell-Marquet, and A. Kansal, Energy pattern analysis of a wastewater treatment plant. Applied Water Science, 2012: p. 1-6.

88. Singh, P., et al., Energy Use and GHG Emission Analysis of Urban Wastewater Infrastructure and Scoping for Use of Renewable Energy Resources. 2016.

This is a post-peer-review, pre-copyedit version of an article published in Water Conservation Science and Engineering. The final authenticated version is available online at: http://dx.doi.org/10.1007/s41101-020-00086-6. 
89. Moreno, R., M. Correia, and F. Martins, Energy and environmental performance of wastewater treatment plants: A statistical approach. Energy Procedia, 2017. 136: p. 296301.

90. Molinos-Senante, M., R. Sala-Garrido, and F. Hernández-Sancho, Benchmarking tools for improving the energy efficiency in wastewater treatment plants. Lecture Notes in Information Technology, 2012. Vol .13: p. 42-47.

91. Molinos-Senante, M., F. Hernandez-Sancho, and R. Sala-Garrido, Benchmarking in wastewater treatment plants: a tool to save operational costs. Clean Technologies and Environmental Policy, 2014. 16(1): p. 149-161.

92. Gómez, T., et al., Assessing the efficiency of wastewater treatment plants: A doublebootstrap approach. Journal of Cleaner Production, 2017. 164: p. 315-324.

93. Lingsten, A. and M. Lundkvist, Nulägesbeskrivning av VA-verkens energianvändning [Facts about Swedish water and wastewater utilities consumption of energy]. 2008.

94. Velasquez-Orta, S.B., et al., Retrofitting options for wastewater networks to achieve climate change reduction targets. Applied Energy, 2018. 218: p. 430-441.

95. Rathor, A., et al., Utility benchmarking for wastewater: synthesis report. 2014, Co-published by Water Environment Research Foundation, Alexandria, Virginia, USA and IWA Publishing, London, UK. IWAP ISBN: 978-1-78040-568-1/1-78040-568-5.

This is a post-peer-review, pre-copyedit version of an article published in Water Conservation Science and Engineering. The final authenticated version is available online at: http://dx.doi.org/10.1007/s41101-020-00086-6. 
Table 1: A summary of energy benchmarking and energy evaluation studies internationally having WWTP energy performance as the main focus (EB - Energy Benchmarking; DEA - Data Envelopment Analysis; OLS - ordinary least squares)

\begin{tabular}{|c|c|c|c|c|c|c|c|c|c|}
\hline \multirow{2}{*}{ Country } & \multirow[b]{2}{*}{$\begin{array}{l}\text { No. of } \\
\text { WWTPs }\end{array}$} & \multirow[b]{2}{*}{ Type of study } & \multirow[b]{2}{*}{ Methodology } & \multirow[b]{2}{*}{ Primary Focus } & \multicolumn{4}{|c|}{ Energy (consumption) expressed as } & \multirow[b]{2}{*}{ References } \\
\hline & & & & & Indicator & $\mathbf{k W h} / \mathbf{P E}^{*} \mathbf{y}$ & $\mathbf{k W h} / \mathbf{m}^{3}$ & $\begin{array}{l}\mathrm{kWh} / \text { pollutant } \\
\text { removed }\end{array}$ & \\
\hline \multirow{3}{*}{ Australia } & 24 & EB & $\begin{array}{l}\text { Statistical } \\
\text { evaluation, } \\
\text { comparative } \\
\text { studies }\end{array}$ & $\begin{array}{l}\text { energy consumption } \\
\text { assessment, EB (guide, } \\
\text { target values) }\end{array}$ & yes & yes & yes & COD & [1] \\
\hline & 142 & EB & $\begin{array}{l}\text { Statistical } \\
\text { evaluation, } \\
\text { comparative } \\
\text { studies }\end{array}$ & $\begin{array}{l}\text { energy consumption } \\
\text { assessment, EB (guide, } \\
\text { target values) }\end{array}$ & yes & yes & yes & COD & {$[79,80]$} \\
\hline & 245 & EB & $\begin{array}{l}\text { Statistical } \\
\text { evaluation, } \\
\text { comparative } \\
\text { studies }\end{array}$ & $\begin{array}{l}\text { energy consumption } \\
\text { assessment, EB (guide, } \\
\text { target values) }\end{array}$ & yes & yes & yes & COD & [81] \\
\hline Austria & 172 & EB & $\begin{array}{l}\text { Statistical } \\
\text { evaluation }\end{array}$ & $\begin{array}{l}\text { energy consumption } \\
\text { assessment, EB (guide, } \\
\text { target values) }\end{array}$ & yes & yes & yes & COD & [41] \\
\hline Austria & 104 & EB & $\begin{array}{l}\text { Statistical } \\
\text { evaluation }\end{array}$ & $\begin{array}{l}\text { energy consumption } \\
\text { assessment, energy self- } \\
\text { sufficiency, operating } \\
\text { costs }\end{array}$ & yes & yes & yes & COD & [42] \\
\hline $\begin{array}{l}\text { Brazil } \\
\text { International }\end{array}$ & 38 & $\begin{array}{l}\text { Energy } \\
\text { evaluation }\end{array}$ & $\begin{array}{l}\text { statistical } \\
\text { evaluation }\end{array}$ & $\begin{array}{l}\text { Energy consumption, } \\
\text { bioenergy }\end{array}$ & yes & no & yes & no & [82] \\
\hline Canada & 289 & $\begin{array}{l}\text { Energy } \\
\text { evaluation }\end{array}$ & $\begin{array}{l}\text { statistical } \\
\text { evaluation }\end{array}$ & $\begin{array}{l}\text { Electric energy } \\
\text { efficiency measures }\end{array}$ & yes & yes & yes & COD & [83] \\
\hline
\end{tabular}

This is a post-peer-review, pre-copyedit version of an article published in Water Conservation Science and Engineering. The final authenticated version is available online at: http://dx.doi.org/10.1007/s41101-020-00086-6. 


\begin{tabular}{|c|c|c|c|c|c|c|c|c|c|}
\hline Chile & 305 & $\begin{array}{l}\text { Energy } \\
\text { intensity }\end{array}$ & $\begin{array}{l}\text { statistical and } \\
\text { regression } \\
\text { analysis }\end{array}$ & $\begin{array}{l}\text { Energy efficiency, } \\
\text { energy use, economies } \\
\text { of scale, regression }\end{array}$ & yes & yes & yes & COD & [84] \\
\hline \multirow[t]{4}{*}{ China } & 599 & $\begin{array}{l}\text { Energy } \\
\text { evaluation }\end{array}$ & $\begin{array}{l}\text { Statistical } \\
\text { evaluation }\end{array}$ & $\begin{array}{l}\text { Energy consumption } \\
\text { assessment, EB }\end{array}$ & yes & no & yes & $\mathrm{TOP}^{\mathrm{a}}$ & [49] \\
\hline & 3095 & $\begin{array}{l}\text { Energy } \\
\text { evaluation }\end{array}$ & $\begin{array}{l}\text { Statistical } \\
\text { evaluation }\end{array}$ & $\begin{array}{l}\text { Treatment technologies, } \\
\text { pollutants, removals, } \\
\text { operating load and } \\
\text { effluent discharge } \\
\text { standards, }\end{array}$ & yes & no & yes & COD & [50] \\
\hline & $4^{b}$ & $\begin{array}{l}\text { Energy } \\
\text { evaluation }\end{array}$ & $\begin{array}{l}\text { Comparative } \\
\text { study, (onsite } \\
\text { Investigations } \\
\text { ) }\end{array}$ & $\begin{array}{l}\text { Energy efficiency, } \\
\text { energy harvesting, } \\
\text { carbon neutrality, } \\
\text { greenhouse gas emission }\end{array}$ & yes & no & yes & COD & [85] \\
\hline & $10^{\mathrm{c}}$ & $\begin{array}{l}\text { Energy } \\
\text { optimisation }\end{array}$ & $\begin{array}{l}\text { Statistical } \\
\text { evaluation }\end{array}$ & $\begin{array}{l}\text { Energy consumption, } \\
\text { energy recovery, energy } \\
\text { self-sufficiency }\end{array}$ & yes & no & yes & COD & {$[15,19]$} \\
\hline France & 7 & $\begin{array}{l}\text { Energy } \\
\text { evaluation }\end{array}$ & $\begin{array}{l}\text { Statistical } \\
\text { evaluation }\end{array}$ & $\begin{array}{l}\text { Electricity consumption, } \\
\text { energy efficiency, } \\
\text { methodological } \\
\text { framework, wastewater } \\
\text { treatment plant }\end{array}$ & yes & no & yes & $\mathrm{t}-\mathrm{N}-\mathrm{NH}_{4}$ & [46] \\
\hline \multirow{4}{*}{ Germany } & - & EB & $\begin{array}{l}\text { Standards and } \\
\text { procedures }\end{array}$ & $\begin{array}{l}\text { energy evaluation, } \\
\text { energy performance } \\
\text { measures }\end{array}$ & yes & yes & yes & COD & [36] \\
\hline & 1,107 & EB & $\begin{array}{l}\text { Statistical } \\
\text { evaluation }\end{array}$ & $\begin{array}{l}\text { energy consumption } \\
\text { assessment, EB (guide, } \\
\text { target values) }\end{array}$ & yes & yes & yes & COD & [33] \\
\hline & 344 & EB & $\begin{array}{l}\text { Theoretical } \\
\text { calculation }\end{array}$ & $\begin{array}{l}\text { energy consumption } \\
\text { assessment, EB (guide, } \\
\text { target values) }\end{array}$ & yes & yes & yes & COD & [35] \\
\hline & 1,107 & EB & $\begin{array}{l}\text { Statistical } \\
\text { evaluation, } \\
\text { literature } \\
\text { investigation }\end{array}$ & EB & yes & yes & yes & COD & [64] \\
\hline
\end{tabular}

39

This is a post-peer-review, pre-copyedit version of an article published in Water Conservation Science and Engineering. The final authenticated version is available online at: http://dx.doi.org/10.1007/s41101-020-00086-6. 


\begin{tabular}{|c|c|c|c|c|c|c|c|c|c|}
\hline & 2,469 & EB & $\begin{array}{l}\text { Statistical } \\
\text { evaluation, } \\
\text { literature } \\
\text { investigation }\end{array}$ & EB & yes & yes & yes & COD & [30] \\
\hline \multirow{3}{*}{ Germany } & 6,823 & EB & $\begin{array}{l}\text { Statistical } \\
\text { evaluation, } \\
\text { literature } \\
\text { investigation } \\
\end{array}$ & EB & yes & yes & yes & COD & [31] \\
\hline & 2,469 & $\begin{array}{l}\text { EB } \\
\text { (evaluation) }\end{array}$ & $\begin{array}{l}\text { Standards and } \\
\text { procedures, } \\
\text { comparative } \\
\text { studies, }\end{array}$ & EB (evaluation) & yes & yes & yes & $\mathrm{COD}$ & [32] \\
\hline & 6,823 & $\begin{array}{l}\text { EB } \\
\text { (regulation) }\end{array}$ & $\begin{array}{l}\text { Regulation, } \\
\text { standards and } \\
\text { Procedures }\end{array}$ & EB regulations & yes & yes & yes & COD & [29] \\
\hline Greece & 10 & $\begin{array}{l}\text { Energy } \\
\text { evaluation }\end{array}$ & $\begin{array}{l}\text { Statistical } \\
\text { evaluation }\end{array}$ & $\begin{array}{l}\text { Carbon footprint, control } \\
\text { strategies, energy } \\
\text { savings, greenhouse gas } \\
\text { emissions, specific } \\
\text { energy consumption }\end{array}$ & yes & yes & no & no & [45] \\
\hline Hungary & 21 & $\begin{array}{l}\text { Energy } \\
\text { evaluation }\end{array}$ & $\begin{array}{l}\text { Statistical } \\
\text { evaluation }\end{array}$ & $\begin{array}{l}\text { Wastewater } \\
\text { characteristics, energy } \\
\text { benchmarking, nitrogen } \\
\text { removal, energy } \\
\text { efficiency, self- } \\
\text { generated electricity. }\end{array}$ & yes & yes & no & COD; TN & [86] \\
\hline India & 1 & $\begin{array}{l}\text { Energy } \\
\text { evaluation }\end{array}$ & $\begin{array}{l}\text { Statistical } \\
\text { evaluation }\end{array}$ & $\begin{array}{l}\text { Energy pattern analyses, } \\
\text { Methodological } \\
\text { framework, Energy } \\
\text { intensity }\end{array}$ & yes & no & yes & no & [87] \\
\hline India & 64 & $\begin{array}{l}\text { Energy } \\
\text { evaluation }\end{array}$ & $\begin{array}{l}\text { Statistical } \\
\text { evaluation }\end{array}$ & $\begin{array}{l}\text { Estimating energy use } \\
\text { and GHG emission, } \\
\text { presents the sources of } \\
\text { energy and carbon } \\
\text { emissions }\end{array}$ & yes & yes & yes & no & [88] \\
\hline
\end{tabular}

This is a post-peer-review, pre-copyedit version of an article published in Water Conservation Science and Engineering. The final authenticated version is available online at: http://dx.doi.org/10.1007/s41101-020-00086-6. 


\begin{tabular}{|c|c|c|c|c|c|c|c|c|c|}
\hline Italy & 1 & $\begin{array}{l}\text { Energy } \\
\text { evaluation }\end{array}$ & $\begin{array}{l}\text { Statistical } \\
\text { evaluation, } \\
\text { process level } \\
\text { optimisation }\end{array}$ & $\begin{array}{l}\text { Energy efficiency, } \\
\text { Biological oxidation, } \\
\text { Aeration }\end{array}$ & yes & yes & yes & COD & {$[70]$} \\
\hline Italy & 241 & EB & $\begin{array}{l}\text { Statistical } \\
\text { evaluation }\end{array}$ & $\begin{array}{l}\text { Benchmarking, electric } \\
\text { energy consumption, } \\
\text { energy efficiency, } \\
\text { performance indicators, } \\
\text { survey }\end{array}$ & yes & yes & yes & COD & [43] \\
\hline Japan & 985 & EB & $\begin{array}{l}\text { Statistical } \\
\text { evaluation }\end{array}$ & $\begin{array}{l}\text { Anaerobic digestion, } \\
\text { electrical energy } \\
\text { consumption, energy } \\
\text { saving, greenhouse gas } \\
\text { emissions }\end{array}$ & yes & no & yes & BOD & [52] \\
\hline \multirow{3}{*}{ Portugal } & 17 & $\begin{array}{l}\text { Energy } \\
\text { performance } \\
\text { evaluation }\end{array}$ & $\begin{array}{l}\text { Statistical } \\
\text { evaluation }\end{array}$ & $\begin{array}{l}\text { Energy performance } \\
\text { assessment, energy } \\
\text { performance indicators }\end{array}$ & yes & no & yes & COD & [47] \\
\hline & $800+$ & $\begin{array}{l}\text { Energy } \\
\text { evaluation }\end{array}$ & $\begin{array}{l}\text { Statistical } \\
\text { evaluation }\end{array}$ & $\begin{array}{l}\text { Benchmark, efficiency, } \\
\text { electrical energy, } \\
\text { management tool, } \\
\text { operational asset }\end{array}$ & yes & no & yes & BOD & [48] \\
\hline & 13 & $\begin{array}{l}\text { Energy } \\
\text { evaluation }\end{array}$ & $\begin{array}{l}\text { Statistical } \\
\text { evaluation }\end{array}$ & $\begin{array}{l}\text { Energy, environment, } \\
\text { statistic, sustainability }\end{array}$ & yes & no & yes & BOD & [89] \\
\hline Slovakia & 68 & EB & $\begin{array}{l}\text { Statistical } \\
\text { evaluation }\end{array}$ & energy benchmarking & yes & no & yes & BOD & [44] \\
\hline \multirow{2}{*}{ Spain } & 177 & $\begin{array}{l}\text { Energy } \\
\text { evaluation }\end{array}$ & $\begin{array}{l}\text { empirical } \\
\text { studies }\end{array}$ & $\begin{array}{l}\text { Energy efficiency, Non- } \\
\text { radial DEA, } \mathrm{CO}_{2} \\
\text { emissions, Energy } \\
\text { saving }\end{array}$ & yes & no & yes & COD & [90] \\
\hline & 192 & $\begin{array}{l}\text { Energy } \\
\text { evaluation }\end{array}$ & $\begin{array}{l}\text { empirical } \\
\text { studies }\end{array}$ & $\begin{array}{l}\text { Energy efficiency, Non- } \\
\text { radial DEA, } \mathrm{CO}_{2} \\
\text { emissions, Energy } \\
\text { saving }\end{array}$ & yes & no & yes & COD & [91] \\
\hline
\end{tabular}

41

This is a post-peer-review, pre-copyedit version of an article published in Water Conservation Science and Engineering. The final authenticated version is available online at: http://dx.doi.org/10.1007/s41101-020-00086-6. 


\begin{tabular}{|c|c|c|c|c|c|c|c|c|c|}
\hline & 30 & EB & $\begin{array}{l}\text { empirical } \\
\text { studies }\end{array}$ & $\begin{array}{l}\text { Bootstrapping, DEA, } \\
\text { Performance }\end{array}$ & yes & no & yes & no & [92] \\
\hline Sweden & 5 & Survey & $\begin{array}{l}\text { Statistical } \\
\text { evaluation }\end{array}$ & $\begin{array}{l}\text { Costs, electricity } \\
\text { consumption, chemical } \\
\text { consumption, manpower }\end{array}$ & yes & yes & no & COD & [37] \\
\hline \multirow{4}{*}{ Switzerland } & 962 & EB & $\begin{array}{l}\text { Theoretical } \\
\text { calculation }\end{array}$ & EB & yes & yes & yes & COD & [34] \\
\hline & - & EB & $\begin{array}{l}\text { Theoretical } \\
\text { calculation }\end{array}$ & EB & yes & yes & yes & COD & [14] \\
\hline & $\mathrm{n} / \mathrm{a}$ & EB & $\begin{array}{l}\text { Statistical and } \\
\text { theoretical } \\
\text { calculation }\end{array}$ & EB & yes & yes & yes & $\mathrm{COD} / \mathrm{BOD}$ & [38] \\
\hline & 256 & $\begin{array}{l}\text { Energy } \\
\text { performance } \\
\text { benchmarking }\end{array}$ & $\begin{array}{l}\text { Statistical } \\
\text { evaluation }\end{array}$ & $\begin{array}{l}\text { Energy consumption, } \\
\text { performance indicators, } \\
\text { saving potential }\end{array}$ & yes & yes & yes & BOD & [93] \\
\hline Sweden & 24 & $\begin{array}{l}\text { Performance } \\
\text { indicators } \\
\text { calculation }\end{array}$ & $\begin{array}{l}\text { Statistical } \\
\text { evaluation }\end{array}$ & $\begin{array}{l}\text { Benchmarking, } \\
\text { operation, performance } \\
\text { indicators, VASS, }\end{array}$ & yes & yes & no & $\mathrm{BOD} / \mathrm{COD}$ & [40] \\
\hline \multirow[t]{2}{*}{ UK } & 2 & $\begin{array}{l}\text { Energy } \\
\text { evaluation }\end{array}$ & $\begin{array}{l}\text { Statistical and } \\
\text { theoretical } \\
\text { calculation }\end{array}$ & $\begin{array}{l}\text { Electrical energy, } \\
\text { manual energy, } \\
\text { mechanical energy, } \\
\text { chemical energy, } \\
\text { oxidation ditch } \\
\end{array}$ & yes & yes & yes & - & [58] \\
\hline & 87 & $\begin{array}{l}\text { Energy } \\
\text { evaluation }\end{array}$ & $\begin{array}{l}\text { Statistical } \\
\text { evaluation }\end{array}$ & $\begin{array}{l}\text { Infrastructure, Carbon } \\
\text { dioxide, Energy use, } \\
\text { Retrofit, Resources }\end{array}$ & yes & no & yes & BOD & [94] \\
\hline USA & 266 & $\begin{array}{l}\text { Energy } \\
\text { performance } \\
\text { benchmarking }\end{array}$ & $\begin{array}{l}\text { Statistical } \\
\text { evaluation }\end{array}$ & $\begin{array}{l}\text { Energy performance, } \\
\text { OLS regression }\end{array}$ & & & & & [55] \\
\hline USA & $2273+$ & $\begin{array}{l}\text { Energy } \\
\text { evaluation }\end{array}$ & $\begin{array}{l}\text { comparative } \\
\text { studies }\end{array}$ & $\begin{array}{l}\text { Performance evaluation, } \\
\text { performance indicators, } \\
\text { database benchmarking. }\end{array}$ & yes & no & yes* & BOD & [95] \\
\hline
\end{tabular}

${ }^{\mathrm{a}} \mathrm{TOP}=(C O D+2 B O D+2 S S+20 T N+100 T P) * V_{W T} ;(\mathrm{kg}) ;$ TOP - total pollution; $V_{W T}-$ wastewater treated volume; ${ }^{\mathrm{b}}$ USA $(15 \mathrm{WWTPS})$, Germany $(10,200 \mathrm{WWTPs})$, China $(14 \mathrm{WWTPS})$ and South Africa; ${ }^{\mathrm{c}}$ China, Germany, Israel, Japan, Korea, South Africa, Spain, Sweden, Switzerland, USA,

42

This is a post-peer-review, pre-copyedit version of an article published in Water Conservation Science and Engineering. The final authenticated version is available online at: http://dx.doi.org/10.1007/s41101-020-00086-6. 
Table 2: 'Ideal value' specific energy consumption (per $\mathrm{m}^{3}$ wastewater) of various wastewater treatment processes for the model-plant of Muller et al. [14] (data adapted from Müller et al. [14]).

\begin{tabular}{|c|c|c|c|}
\hline \multirow[b]{2}{*}{ Wastewater treatment process stage } & \multicolumn{3}{|c|}{$\begin{array}{l}\text { Specific electricity consumption of model-plant } \\
100,000 \mathrm{PE}\end{array}$} \\
\hline & $\begin{array}{c}\mathrm{Wh} / \mathrm{m}^{3} \\
\text { wastewater }^{\text {a }}\end{array}$ & $\mathrm{kWh} / \mathrm{PE}^{*} \mathrm{y}$ & $\begin{array}{l}\text { model-plant } \\
\mathrm{kWh} / \mathrm{d}\end{array}$ \\
\hline \multicolumn{4}{|l|}{ Outside the WWTP boundaries } \\
\hline Storm water overflow basins (catchment basin) & 4 & & $\mathrm{~b}$ \\
\hline \multicolumn{4}{|l|}{ Within WWTP boundaries } \\
\hline wastewater lift station for $3 \mathrm{~m}$ delivery head & 13.9 & 1.93 & 528 \\
\hline Rakes & 0.7 & 0.09 & 25 \\
\hline Grit chamber (aerated grit chamber) & 5.5 & 0.76 & 209 \\
\hline \multicolumn{4}{|l|}{ Preliminary sedimentation } \\
\hline incl. primary sludge pumping station & 1.1 & 0.15 & 42 \\
\hline Aeration/ blowers & 98.9 & 13.72 & 3760 \\
\hline Circulation (denitrification) & 12.6 & 1.75 & 480 \\
\hline Recirculation & 5.7 & 0.79 & 216 \\
\hline Return activated sludge & 6.9 & 0.96 & 262 \\
\hline Aeration with nitrogen elimination & 124.1 & 17.22 & 4,718 \\
\hline Option: fluid-bed reactor process & 252.3 & 35 & 9,589 \\
\hline Option: fixed-bed reactor process & 144.2 & 20 & 5,479 \\
\hline Option: MBR & 360.5 & 50 & 13,699 \\
\hline Option: trickling filter with nitrification & 54.7 & 7.59 & 2080 \\
\hline $\begin{array}{l}\text { Option: } \mathrm{RBC} \text { - rotating biological contactor with nitrification } \\
(10,000 \mathrm{PE})^{\mathrm{b}}\end{array}$ & 15.9 & 2.2 & \\
\hline Secondary clarification - recirculation sludge pumping station & 1.6 & 0.22 & 61 \\
\hline Precipitation dosing - Simultaneous precipitation & 0.3 & 0.04 & 11 \\
\hline \multicolumn{4}{|l|}{ Filtration, including lifting } \\
\hline downward flow filter ${ }^{c}$ & 22.5 & 3.12 & 855 \\
\hline
\end{tabular}

43

This is a post-peer-review, pre-copyedit version of an article published in Water Conservation Science and Engineering. The final authenticated version is available online at: http://dx.doi.org/10.1007/s41101-020-00086-6. 


\begin{tabular}{|l|l|l|l|}
\hline Continuous flushed up flow-filter & 1.9 & 2.5 & 680 \\
\hline Cylindrical filter system & 9.8 & 1.37 & 373 \\
\hline Micro-screening & 22 & 3.05 & 836 \\
\hline $\begin{array}{r}\text { Sum model-plant 100,000 PE } \\
\text { (takes into account only Bold process stages) }\end{array}$ & $\mathbf{1 6 9 . 7}$ & $\mathbf{2 3 . 5}$ & $\mathbf{6 , 4 4 9}$ \\
\hline
\end{tabular}

${ }^{a}$ Basis of model-plant $38,000 \mathrm{~m}^{3} / \mathrm{d}$ wastewater $(380 \mathrm{~L} / \mathrm{PE}$ d)

${ }^{b}$ Referring to model-plant not advisable/appropriate

${ }^{c}$ Includes wastewater lifting station with 3 m pumping head 
Table 3: 'Ideal value' specific energy consumption (per $1 \mathrm{~m}^{3}$ sludge resp. 1 ton of total solids (1t TS)) of various sludge treatment processes for the model-plant of Muller et al. [14] (data adapted from Müller et al. [14])

\begin{tabular}{|c|c|c|c|c|}
\hline \multirow{2}{*}{\multicolumn{2}{|c|}{ Sludge treatment processes stage }} & \multicolumn{3}{|c|}{$\begin{array}{l}\text { Specific electricity consumption of model- } \\
\text { plant } 100,000 \mathrm{PE}\end{array}$} \\
\hline & & $\begin{array}{l}\mathrm{kWh} / \mathrm{m}^{3} \\
\text { sludge }^{\mathrm{a}}\end{array}$ & $\mathrm{kWh} / \mathrm{PE}^{*} \mathrm{y}$ & $\begin{array}{c}\text { model-plant } \\
\mathrm{kWh} / \mathrm{d}\end{array}$ \\
\hline coarse materials removal & sludge screening & 0.1 & 0.05 & 13 \\
\hline \multirow{3}{*}{$\begin{array}{l}\text { Pre-thickening } \\
\text { primary sludge } \\
\left(174 \mathrm{~m}^{3} / \mathrm{d}\right)\end{array}$} & static & 0.1 & $\mathbf{0 . 0 7}$ & 20 \\
\hline & rotary drum screens & 0.3 & 0.16 & 45 \\
\hline & press & 0.5 & 0.29 & 80 \\
\hline \multirow{3}{*}{$\begin{array}{l}\text { Pre-thickening } \\
\text { excess-sludge } \\
\left(620 \mathrm{~m}^{3} / \mathrm{d}\right)\end{array}$} & rotary drum screens & 0.3 & 0.73 & 200 \\
\hline & decanter & 0.6 & 1.46 & 400 \\
\hline & flotation & 1 & 2.19 & 600 \\
\hline \multirow{2}{*}{$\begin{array}{l}\text { Stabilisation } \\
\left(155 \mathrm{~m}^{3} / \mathrm{d} \text { raw-sludge }\right)\end{array}$} & anaerobic-mesophilic & 1.9 & 1.1 & 300 \\
\hline & anaerobic-psychrophilic & 1 & 0.58 & 160 \\
\hline$\left(155 \mathrm{~m}^{3} / \mathrm{d}\right.$ raw-sludge $)$ & ultrasound disintegration & 1 & 0.55 & 152 \\
\hline \multirow{6}{*}{$\begin{array}{l}\text { Dewatering } \\
\left(155 \mathrm{~m}^{3} / \mathrm{d} \text { digested-sludge }\right)\end{array}$} & static post-thickening & 0.1 & 0.07 & 20 \\
\hline & decanter & 1 & 0.58 & 160 \\
\hline & high dewatering centrifuge & 1.3 & $\mathbf{0 . 7 3}$ & 200 \\
\hline & belt filter press & 0.8 & 0.44 & 120 \\
\hline & chamber filter press & 1.6 & 0.91 & 250 \\
\hline & membrane filter press & 2.5 & 1.39 & 380 \\
\hline Drying & thermal & 26.7 & 1.46 & 400 \\
\hline \multicolumn{2}{|l|}{ Temporary storage } & 1 & & \\
\hline \multicolumn{2}{|l|}{ sludge reuse/disposal } & & & \\
\hline sludge pumping station & digested sludge & \multicolumn{3}{|c|}{ allocated to treatment stages } \\
\hline \multicolumn{2}{|c|}{$\begin{array}{l}\text { Sum model-plant 100,000 PE } \\
\text { (take into account only Bold process stage) }\end{array}$} & & 2.7 & 733 \\
\hline
\end{tabular}

${ }^{a}$ Reference basis $1 \mathrm{~m}^{3}$ sludge in the inlet to the respective treatment stage

This is a post-peer-review, pre-copyedit version of an article published in Water Conservation Science and Engineering. The final authenticated version is available online at: http://dx.doi.org/10.1007/s41101-020-00086-6. 
Table 4: 'Ideal value' - specific energy consumption for infrastructure for the model-plant of Muller et al. [14] (data adapted from Müller et al. [14])

\begin{tabular}{|c|c|c|c|c|}
\hline & & \multicolumn{3}{|c|}{$\begin{array}{l}\text { Specific electricity consumption of model- } \\
\text { plant } 100,000 \mathrm{PE}\end{array}$} \\
\hline \multicolumn{2}{|c|}{ Infrastructure process stage } & $\mathrm{kWh} / \mathrm{Unit}$ & $\mathrm{kWh} / \mathrm{PE}^{*} \mathrm{y}$ & $\begin{array}{c}\text { model-plant } \\
\mathrm{kWh} / \mathrm{d}\end{array}$ \\
\hline Operations building & light, lab, workshop & & 0.18 & 50 \\
\hline $\begin{array}{l}\text { Supplies } \\
\text { potable water }\end{array}$ & from network & extern & & \\
\hline service water/process water & internal network & $0.3^{\mathrm{a}}$ & 0.26 & 70 \\
\hline compressed air & internal network & $0.1^{\mathrm{b}}$ & 0.05 & 13 \\
\hline Heating & & & 0.37 & 100 \\
\hline Ventilation system & & & 0.15 & 40 \\
\hline \multicolumn{2}{|c|}{ Exhaust air purification (depending on local conditions) } & & 0.58 & 160 \\
\hline (take into acc & $\begin{array}{l}\text { model-plant 100,000 PE } \\
t \text { only Bold process stage) }\end{array}$ & & 1.6 & 433 \\
\hline
\end{tabular}

a per $1 \mathrm{~m}^{3}$ service water

${ }^{b}$ per $1 m^{3}$ compressed air (Suction volume) 
Table 5: Total specific energy consumption for the model-plant of Muller et al. [14] (data adapted from Müller et al. [14]).

\begin{tabular}{|l|c|c|}
\hline & $\begin{array}{c}\text { Energy (electricity) consumption } \\
\text { of model plant 100,000 PE }\end{array}$ \\
\hline $\begin{array}{l}\text { Activated sludge plants with N-elimination and pre-treatment } \\
\text { (for all treatment stages also energy-efficient process/New } \\
\text { installations) }\end{array}$ & $\mathrm{kWh/PE*y}$ & $\begin{array}{c}\text { model-plant } \\
\mathrm{kWh} / \mathrm{d}\end{array}$ \\
\hline Wastewater treatment & 23.5 & 6,449 \\
\hline Sludge treatment & 2.7 & 733 \\
\hline Infrastructure and others & 1.6 & 433 \\
\hline Total for the entire model-plant & $\mathbf{2 7 . 8}$ & $\mathbf{7 , 6 1 5}$ \\
\hline
\end{tabular}

This is a post-peer-review, pre-copyedit version of an article published in Water Conservation Science and Engineering. The final authenticated version is available online at: http://dx.doi.org/10.1007/s41101-020-00086-6. 
Table 6: Guide values in kWh/PEBOD60*y for specific energy consumption in relation to SC and biological treatment of Baumann at al. [31] (data adapted from Baumann et al. [31]).

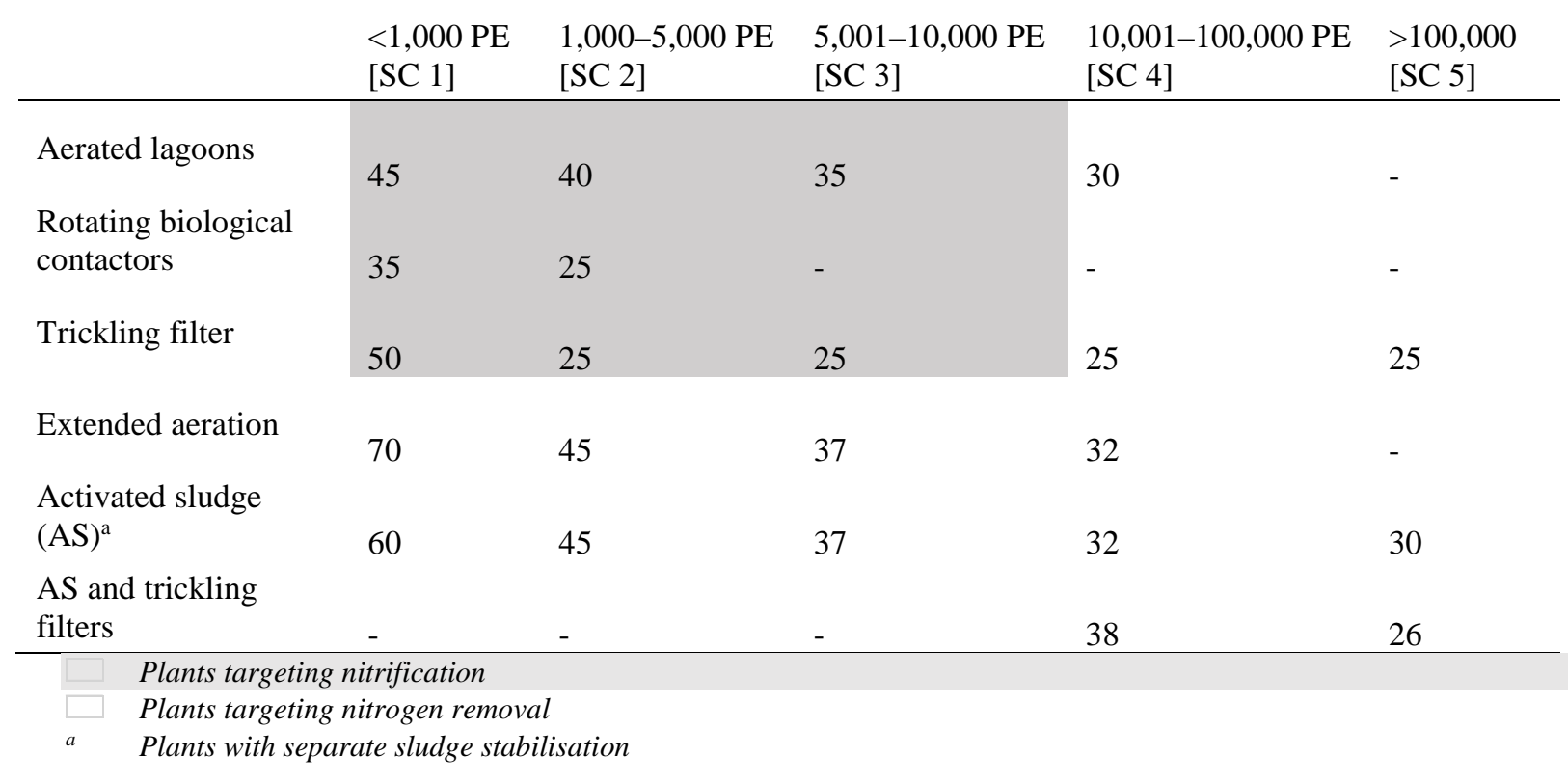


Table 7: Target Values in $\mathrm{kWh} / \mathrm{PE}_{\mathrm{BOD} 60}{ }^{*} \mathrm{y}$ for specific energy consumption in relation to SC and biological treatment of Baumann at al. [31] (data adapted from Baumann et al. [31]).

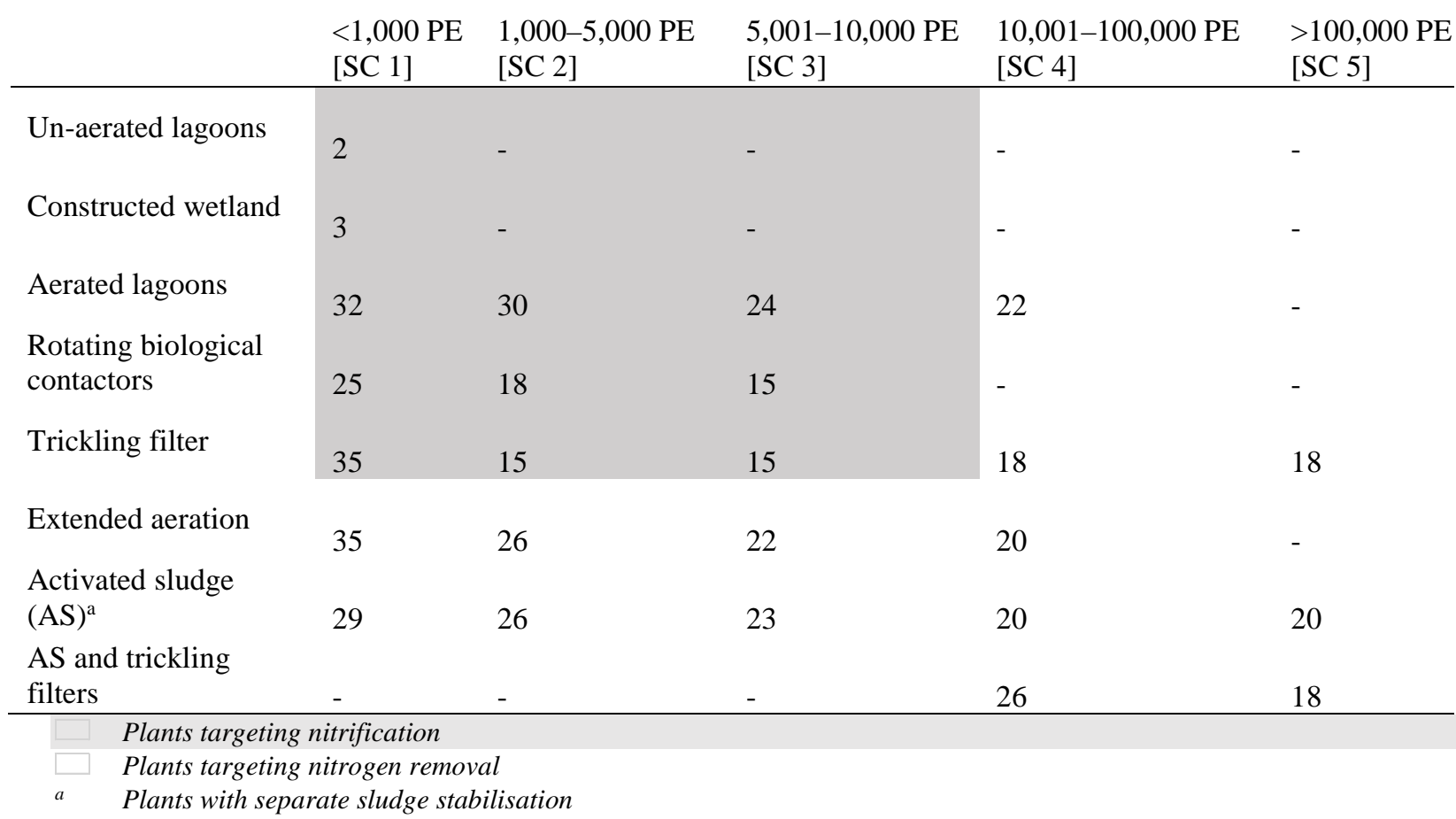

